\section{Pacific Northwest}

National Laboratory

Operated by Battelle for the

U.S. Department of Energy

\title{
Facility Energy Decision System (FEDS) Assessment Report for Fort Buchanan, Puerto Rico
}

\author{
WD Chvala, Jr. DR Dixon \\ AE Solana
}

February 2005

Prepared for the U.S. Department of Energy

under Contract DE-AC05-76RL01830 


\title{
DISCLAIMER
}

This report was prepared as an account of work sponsored by an agency of the United States Government. Neither the United States Government nor any agency thereof, nor Battelle Memorial Institute, nor any of their employees, makes any warranty, express or implied, or assumes any legal liability or responsibility for the accuracy, completeness, or usefulness of any information, apparatus, product, or process disclosed, or represents that its use would not infringe privately owned rights. Reference herein to any specific commercial product, process, or service by trade name, trademark, manufacturer, or otherwise does not necessarily constitute or imply its endorsement, recommendation, or favoring by the United States Government or any agency thereof, or Battelle Memorial Institute. The views and opinions of authors expressed herein do not necessarily state or reflect those of the United States Government or any agency thereof.

\author{
PACIFIC NORTHWEST NATIONAL LABORATORY \\ operated by \\ BATTELLE \\ for the \\ UNITED STATES DEPARTMENT OF ENERGY \\ under Contract DE-AC05-76RL01830
}

Printed in the United States of America
Available to DOE and DOE contractors from the Office of Scientific and Technical Information,
P.O. Box 62, Oak Ridge, TN 37831-0062;
ph: (865) 576-8401
fax: $(865)$ 576-5728
email: reports@adonis.osti.gov

\begin{abstract}
Available to the public from the National Technical Information Service, U.S. Department of Commerce, 5285 Port Royal Rd., Springfield, VA 22161 ph: (800) 553-6847 fax: $(703) 605-6900$ email: orders@ntis.fedworld.gov online ordering: http://www.ntis.gov/ordering.htm
\end{abstract}

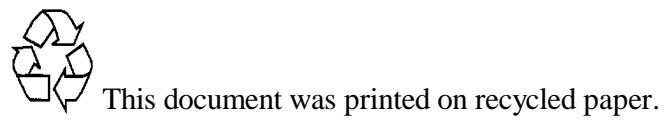




\title{
Facility Energy Decision System (FEDS) Assessment Report for Fort Buchanan, Puerto Rico
}

\author{
W. D. Chvála, Jr. \\ A. E. Solana \\ D. R. Dixon
}

January 2005

\author{
Prepared for the \\ U.S. Army Installation Management Agency \\ Southeast Region Office \\ under Contract DE-AC05-76RL01830 \\ Related Services
}

With funding support from the U.S. Department of Energy

Office of Energy Efficiency and Renewable Energy

Federal Energy Management Program

Under Contract DE-AC05-76RL01830

Pacific Northwest National Laboratory

Richland, Washington 99352 


\section{Executive Summary}

The assessment was performed by a team of engineers from Pacific Northwest National Laboratory (PNNL) under contract to the Installation Management Agency (IMA) Southeast Region Office (SERO). The effort used the Facility Energy Decision System (FEDS) model to determine how energy is consumed at Fort Buchanan, identify the most cost-effective energy retrofit measures, and calculate the potential energy and cost savings.

A team of engineers from PNNL visited Fort Buchanan on April 26-28, 2004 to collect data for the FEDS assessment. During this visit, PNNL engineers collected energy-related information and data from 41 representative buildings and other energy systems for input into the FEDS model.

The economic results presented in this report are based on the use of two different sources of capital funds to implement the energy projects; appropriated funds, and alternative financing (e.g., ESPC). The alternative financing economic input assumptions are for generic ESPC financing to illustrate the differences that the source of capital makes on the technology choices. The FEDS software is capable of performing the comprehensive assessment using other sources of capital (e.g., utility financing) with their distinct economic inputs. Thus, the site is encouraged to re-run the FEDS software using site-specific alternative financing options and reassess the results.

This report documents the findings of the FEDS assessment and model results for appropriated funds and alternative financing sources of capital for the projects. A complete list of the 119 cost-effective energy- and cost-reducing retrofit measures is included in Appendix C-1 for projects funded using appropriated fund source of capital and a complete list of 91 cost-effective energy and cost-reducing retrofit measures is included in Appendix C-2 for projects funded using alternative financing source of capital.

Table ES.1 summarizes the results of the energy assessment by retrofit category for appropriated fund source of capital. Table ES.2 summarizes the results of the energy assessment by retrofit category for alternative financing source of capital. 
Table ES.1. Summary of Potential Energy and Cost Savings for Fort Buchanan Using Appropriated Source of Capital

\begin{tabular}{|l|r|r|r|r|r|c|}
\hline $\begin{array}{c}\text { Retrofit } \\
\text { Category }\end{array}$ & $\begin{array}{c}\text { Energy } \\
\text { Savings } \\
\mathbf{M M B t u / y r )}\end{array}$ & $\begin{array}{c}\text { 1st Year } \\
\text { Savings } \\
\mathbf{( \$ / y r )}\end{array}$ & $\begin{array}{c}\text { Installed } \\
\text { Cost (\$) }\end{array}$ & $\begin{array}{c}\text { Net Present } \\
\text { Value (\$) }\end{array}$ & SIR & $\begin{array}{c}\text { Simple } \\
\text { Payback } \\
\text { (yr) }\end{array}$ \\
\hline Cooling & 5,122 & 169,931 & $1,524,565$ & 619,686 & 1.64 & 9.0 \\
\hline Envelope & 12,181 & 341,656 & $1,974,381$ & $4,033,877$ & 3.11 & 5.8 \\
\hline Hot Water & 2,438 & 61,203 & 166,851 & 680,077 & 4.93 & 2.7 \\
\hline Lighting & 8,463 & 278,332 & $1,500,480$ & $3,384,964$ & 3.25 & 5.4 \\
\hline Grand Total & $\mathbf{2 8 , 2 0 4}$ & $\mathbf{8 5 1 , 1 2 2}$ & $\mathbf{5 , 1 6 6 , 2 7 7}$ & $\mathbf{8 , 7 1 8 , 6 0 4}$ & $\mathbf{2 . 9 1}$ & $\mathbf{6 . 1}$ \\
\hline
\end{tabular}

Table ES.2. Summary of Potential Energy and Cost Savings for Fort Buchanan Using Alternative Financing Source of Capital

\begin{tabular}{|l|r|r|r|r|r|c|}
\hline $\begin{array}{c}\text { Retrofit } \\
\text { Category }\end{array}$ & $\begin{array}{c}\text { Energy } \\
\text { Savings } \\
\mathbf{( M M B t u / y r )}\end{array}$ & $\begin{array}{c}\text { 1st Year } \\
\text { Savings } \\
\mathbf{( \$ / y r )}\end{array}$ & $\begin{array}{c}\text { Installed } \\
\text { Cost (\$) }\end{array}$ & $\begin{array}{c}\text { Net Present } \\
\text { Value (\$) }\end{array}$ & SIR & $\begin{array}{c}\text { Simple } \\
\text { Payback } \\
\text { (yr) }\end{array}$ \\
\hline Cooling & 2,145 & 76,482 & 511,242 & 365,427 & 1.77 & 6.7 \\
\hline Envelope & 9,013 & 275,507 & $1,171,372$ & $1,591,974$ & 2.38 & 4.3 \\
\hline Hot Water & 2,177 & 56,903 & 109,966 & 461,311 & 4.68 & 1.9 \\
\hline Lighting & 6,844 & 254,425 & $1,020,132$ & $1,537,791$ & 2.56 & 4.0 \\
\hline Grand Total & $\mathbf{2 0 , 1 7 9}$ & $\mathbf{6 6 3 , 3 1 7}$ & $\mathbf{2 , 8 1 2 , 7 1 2}$ & $\mathbf{3 , 9 5 6 , 5 0 3}$ & $\mathbf{2 . 4 5}$ & $\mathbf{4 . 2}$ \\
\hline
\end{tabular}

For appropriated funds source of capital in Table ES.1, Fort Buchanan can save 28,204 MMBtu/year and \$851,000/year if all cost-effective retrofits are implemented. The site can reduce its energy consumption by $15.7 \%$ by implementing the 119 cost-effective energy- and cost-reducing projects identified in this report.

For alternative financing source of capital in Table ES.2, Fort Buchanan can save 20,179 MMBtu/year and \$663,000/year if all cost-effective retrofits are implemented. The site can reduce its energy consumption by $11.2 \%$ by implementing the 91 cost-effective energy- and cost-reducing projects identified in this report.

In addition to this report, the Fort Buchanan energy manager will receive a complete record of the FEDS input and output files. The FEDS input files consist of the relevant building and equipment data collected and the assumptions made to perform the complex engineering analysis. The FEDS output files contain considerably more detail in support of future project development. 


\section{Contents}

Executive Summary .......................................................................................... iii

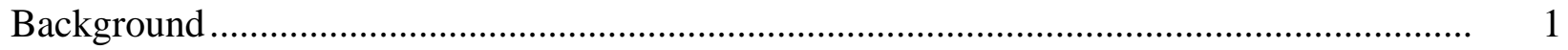

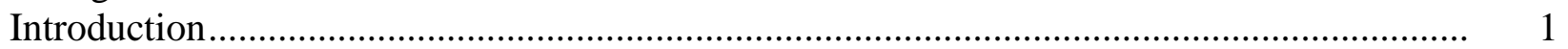

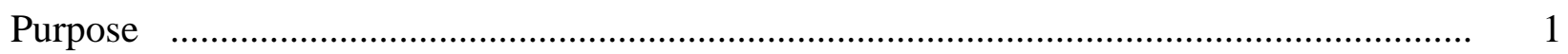

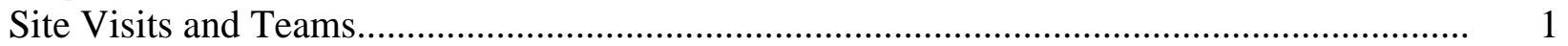

Summary of Relevant Information Collected ........................................................ 2

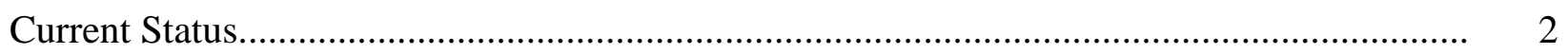

Description of Facilities ........................................................................................

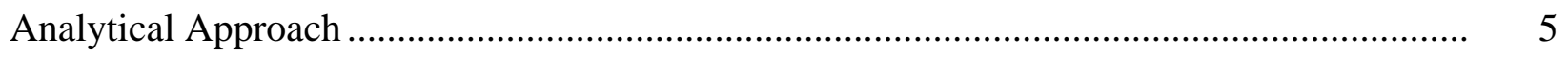

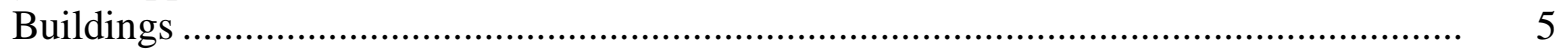

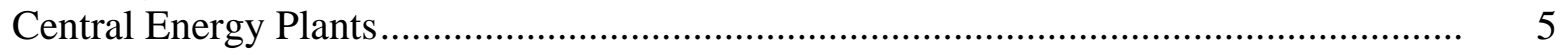

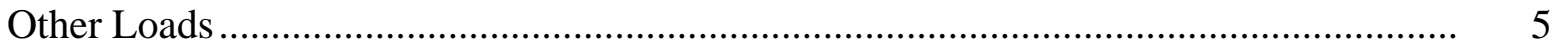

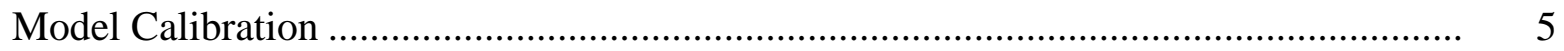

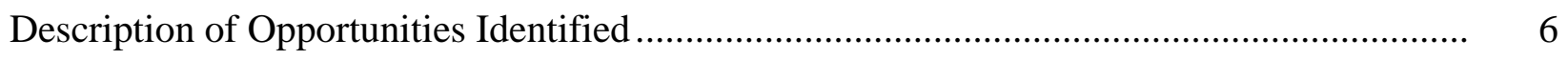

Recommendations for More In-Depth Assessments................................................... 9

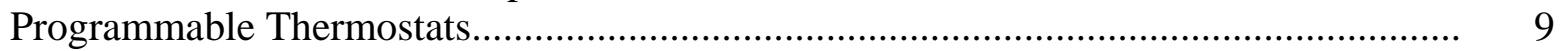

Humidity Control ............................................................................................. 9

Additional Envelope Measures .......................................................................... 10

Appendix A - FEDS Data Collection Form ............................................................ 11

Appendix B - Facility Category Descriptions and Associated Buildings........................ 13

Appendix C-1 - Comprehensive List of Cost-Effective Projects Identified from the FEDS Assessment Using Appropriated Source of Capital ...................... 17

Appendix C-2 - Comprehensive List of Cost-Effective Projects Identified from the FEDS Assessment Using Alternative Financing Source of Capital .......... 27 


\section{Figures}

1 Fort Buchanan Energy Reduction Glide Path.

\section{Tables}

ES.1 Summary of Potential Energy and Cost Savings for Fort Buchanan Using Appropriated Source of Capital

ES.2 Summary of Potential Energy and Cost Savings for Fort Buchanan Using Alternative Financing Source of Capital.... iv

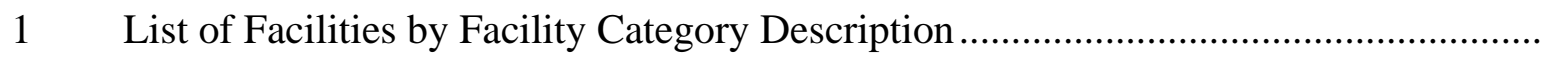

2 Summary of All Cost-Effective Projects Identified from the FEDS Assessment for Fort Buchanan Using Appropriated Source of Capital.

3 Summary of All Cost-Effective Projects Identified from the FEDS Assessment for Fort Buchanan Using Alternative Financing as the Source of Capital.... 


\section{Background}

Fort Buchanan is the only active Army Post in the Caribbean Basin area. It supports the reserve components and active component soldiers in Puerto Rico and U.S. Virgin Islands as a power projection platform to mobilize the nation's only fully bilingual and bicultural force, a definite asset for Department of Defense (DoD) relations with central and South America. Its principal mission is the mobilization, readiness, and actual deployment of some 15,000 reserve component soldiers in Puerto Rico and the U.S. Virgin Islands. The installation also provides support to DoD operations in the Caribbean area (e.g., Operation Restore Democracy).

Spanning only 476 acres are approximately 511 buildings totaling over 2.1 million square feet of floor area, which includes 224 family housing units totaling over 449 thousand square feet. The family housing total is expected to decrease to 119 units by fiscal year (FY) 2006. The impact on the total Fort Buchanan square footage area is expected to be approximately 1.8 million square feet. The oldest buildings still in use at Fort Buchanan date back to 1941. Most family housing was built in the 1950s and 1960s.

\section{Introduction}

This report contains the results of the Facility Energy Decision System (FEDS) assessment conducted at Fort Buchanan, Puerto Rico by Pacific Northwest National Laboratory (PNNL). The scope of this activity was based on performing a site-wide energy assessment using the FEDS process to identify cost-effective energy- and cost-reduction projects. The results of the FEDS assessment will be used by the installation to develop a Long-Range Energy Management Plan that will outline how Fort Buchanan will meet the goals of Executive Order 13123 by FY 2010.

\section{Purpose}

The purpose of this report is to present the findings resulting from the site visit performed April 26-28, 2004 and subsequent modeling and analysis. The objective of the site visit was to collect the necessary data to conduct a detailed site assessment using the FEDS process, which would result in a list of cost-effective, energy- and cost-reduction projects for Fort Buchanan, and provide the necessary data and information to develop the Long-Range Energy Management Plan.

\section{Site Visits and Teams}

The formal kickoff of the site assessment at Fort Buchanan was held on the morning of April 26, 2004. The PNNL team presented an overview of the FEDS assessment process, the long-range energy management plans, and schedule for the Fort Buchanan work. Participating in this meeting were representatives from the Directorate of Public Works (DPW) and PNNL, including the following:

1. Jesus Gimenez - Energy Manager

2. Alfredo J. Riera, P.E. - Director Public Works

3. Ferdinand Torres - Operations Chief 
4. Felix M. Mariani, Chief, Environmental Division

5. Rafael Perez - Acting Master Planner

6. Amy Solana - PNNL

7. Bill Chvala - PNNL

\section{Summary of Relevant Information Collected}

During the site assessment visit, the following activities occurred and relevant information collected:

- Interview with Jesus Gimenez, Energy Manager

0 List of energy-efficiency and cost reduction projects implemented at the Fort in the past

o List of proposed energy-related projects under current consideration by the Fort

- Interview with Rafael Perez from Master Planning office

o Presentation describing recently completed and planned construction

o Important discussion on the status of the construction moratorium

o List of facilities currently programmed to be demolished over the next few years

o Demolition list for family housing

- Other data collected

o RADDS reporting information specific to FY 2003

o Electric rate schedule information

o Copies of site plan and detailed maps, including one for each school and floor plans for the PX/Commissary and Building 556

o Water and sewer consumption and cost for FY 2003

o LPG cost and consumption for hotel to represent site-wide LPG cost

o Memo on increase in LPG price for FY 2004

o ECIP proposals for control systems and lighting retrofits, and for photovoltaic street lighting systems

o Inventory of family housing exterior lighting fixtures

o Inventory of generators onsite

o Inventory of cooling systems for each building onsite

o Some electrical meter data for part of FY 2003

Site staff helped confirm that representative buildings for each building group were appropriate and accessible to the team. Detailed building audits were conducted on 28 buildings. The FEDS data collection forms shown in Appendix A indicate the type of information collected for each building.

\section{Current Status}

Executive Order 13123 requires that energy use intensity (MMBtu/ft ${ }^{2} /$ year) be reduced by $30 \%$ in 2005 and $35 \%$ in 2010 as compared to a 1985 baseline. Fort Buchanan is subject to this goal and is behind of the compliance glide path-103.5\% above the FY 1985 baseline as compared to the FY 2004 targeted reduction of $28.5 \%$ (see figure 1). Fort Buchanan has increased energy intensity significantly since 1985 mainly because of a major increase in air conditioning in administrative facilities, barracks, and family housing. Most of these facilities were not 
originally designed for air conditioning and do not have the appropriate insulation, windows, and moisture barriers in the walls, ceilings, and around the foundation.

Fort Buchanan is far above the compliance glide path, resulting in a need to reduce its energy intensity by $9.7 \%$ every year to meet the 2010 goal. In 2003, Fort Buchanan's total energy consumption was $171,711 \mathrm{MMBtu}$, with a cost of $\$ 2,783,000$. The historical energy intensity for Fort Buchanan is shown in Figure 1.

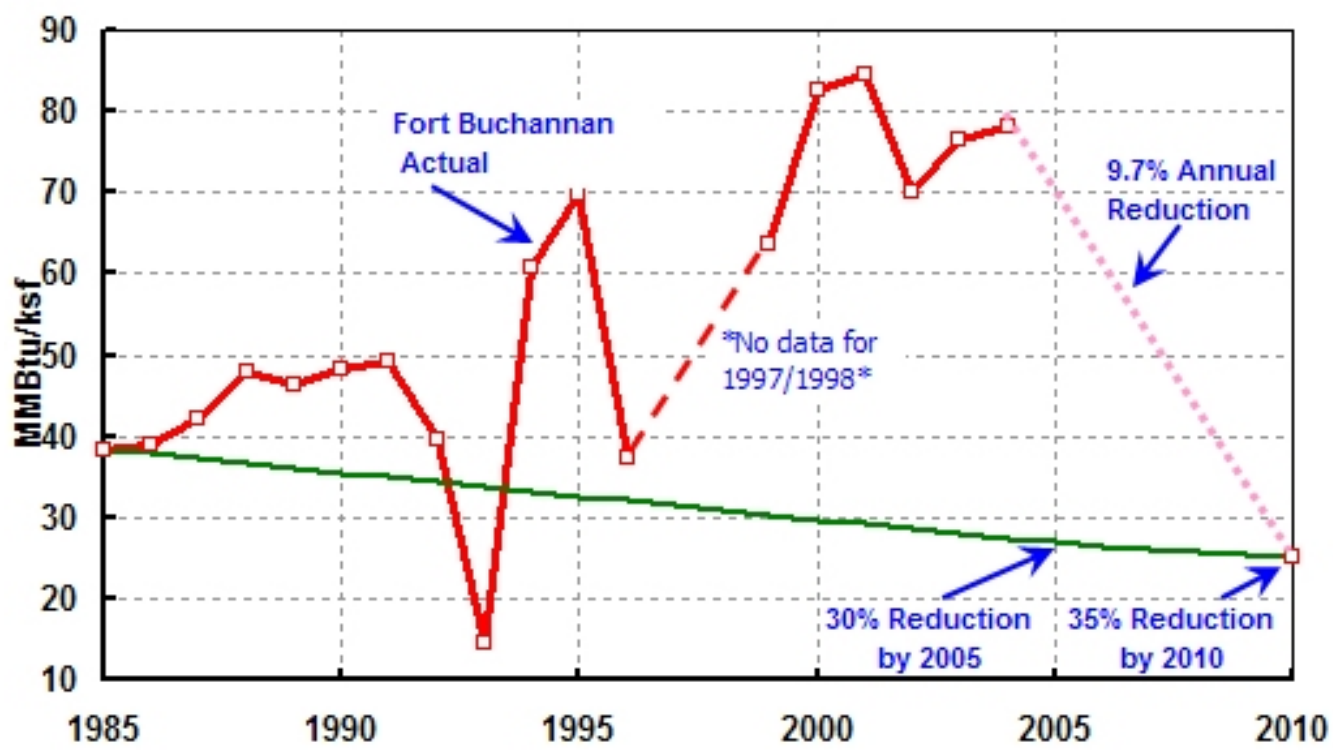

Note: No values available for 1997 or 1998

Figure 1. Fort Buchanan Energy Reduction Glide Path

\section{Description of Facilities}

Fort Buchanan is located near San Juan, Puerto Rico, and during FY 2004 consisted of

511 buildings totaling approximately 2.1 million square feet, which includes 224 family housing facilities totaling over 449 thousand square feet. The scope of the FEDS assessment performed at Fort Buchanan included all facilities in the primary cantonment area including family housing.

Table 1 identifies the list of facility categories for the FEDS assessment and the facility proxies for each category. The facilities at Fort Buchanan were divided into 33 categories for modeling based on the 41 buildings visited by the team. Please note that all school buildings are included in building sets $10 \mathrm{tr}, 10 \mathrm{is}, 10 \mathrm{es}, 10 \mathrm{~ms}, 10 \mathrm{hs}$, and $50 \%$ of the area of $60 \mathrm{c}$ (cafeterias). A complete listing of the facilities (buildings) associated with each FEDS facility category is provided in Appendix B. 
Table 1. List of Facilities by Facility Category Description

\begin{tabular}{|c|c|c|c|c|}
\hline Facility Category Description & $\begin{array}{c}\text { Proxy } \\
\text { Facility } \\
\text { No. }\end{array}$ & $\begin{array}{c}\text { FEDS } \\
\text { Facility } \\
\text { Category } \\
\text { Code }\end{array}$ & $\begin{array}{l}\text { Facility } \\
\text { Quantity }\end{array}$ & $\begin{array}{c}\text { Category } \\
\text { Area (sq. ft.) }\end{array}$ \\
\hline Overhead Protection & 179 & 1 & 64 & 17,753 \\
\hline Administration with Storage & 509 & $10 \mathrm{a}$ & 7 & 57,072 \\
\hline Administration with Storage* & 556 & 10b1 & 1 & 41,037 \\
\hline Administration with Maintenance* & 556 & $10 \mathrm{~b} 2$ & 1 & 13,842 \\
\hline Training Centers & 1305 & $10 \mathrm{c}$ & 17 & 152,725 \\
\hline Smaller 1940s General Purpose Administration & 225 & $10 \mathrm{~d}$ & 24 & 94,232 \\
\hline Larger 1940s General Purpose Administration & $\begin{array}{c}152,390 \\
399\end{array}$ & $10 \mathrm{e}$ & 6 & 99,228 \\
\hline 1950s \& 60s General Purpose Administration & 203 & $10 f$ & 28 & 70,258 \\
\hline Newer General Purpose Administration & 540 & $10 \mathrm{~g}$ & 9 & 38,685 \\
\hline School Trailers & 92,1066 & $10 \operatorname{tr}$ & 34 & 47,346 \\
\hline Intermediate School & 78 & 10is & 12 & 49,020 \\
\hline Elementary School & 1031 & $10 \mathrm{es}$ & 13 & 55,473 \\
\hline Middle School & 1073 & $10 \mathrm{~ms}$ & 9 & 73,485 \\
\hline High School & 1062 & $10 \mathrm{hs}$ & 3 & 80,392 \\
\hline Clinics & 21 & 21 & 6 & 23,513 \\
\hline Older Barracks & 1300,1301 & $30 \mathrm{~b}-1$ & 5 & 47,411 \\
\hline 2000 Army Lodging & 678 & $30 b-2$ & 4 & 54,526 \\
\hline Las Colinas & 807,815 & $30 \mathrm{sf}-1$ & 29 & 75,929 \\
\hline Coconut Grove & 1134 & $30 \mathrm{sf}-2$ & 127 & 168,780 \\
\hline Coqui Gardens & 1280 & $30 \mathrm{sf}-3$ & 48 & 109,328 \\
\hline Buchanan Heights & 1011 & $30 s f-4$ & 20 & 94,985 \\
\hline Cold Storage* $^{*}$ & 517 & $40 \mathrm{a} 1$ & 1 & 8,585 \\
\hline Administration \& Warehouse of Cold Storage* & 517 & $40 \mathrm{a} 2$ & 1 & 8,586 \\
\hline 1940s Storage & 614 & $40 \mathrm{~b}$ & 9 & 100,640 \\
\hline Large Storage* & 541 & $40 \mathrm{c} 1$ & 1 & 47,735 \\
\hline Administration of Large Storage* & 541 & $40 \mathrm{c} 2$ & 1 & 2,515 \\
\hline Vehicle Maintenance* & 528 & $50-1$ & 1 & 6,558 \\
\hline Administration of Vehicle Maintenance* & 528 & $50-2$ & 1 & 3,531 \\
\hline Commissary* & 689 & $60 \mathrm{a} 1$ & 1 & 92,290 \\
\hline $\mathrm{PX}^{*}$ & 689 & $60 \mathrm{a} 2$ & 1 & 118,853 \\
\hline Exchange / Security & 613 & $60 \mathrm{~b}$ & 5 & 101,565 \\
\hline Dining & 660 & $60 \mathrm{c}$ & 7 & 82,925 \\
\hline Miscellaneous MWR & $\begin{array}{c}148,167 \\
168 \\
\end{array}$ & 80 & 20 & 83,109 \\
\hline Total & 41 Proxies & & 511 & $2,121,921$ \\
\hline
\end{tabular}




\section{Analytical Approach}

The general approach was to develop a model of the buildings and other energy-related infrastructure at Fort Buchanan, calibrate that model to actual FY 2003 energy use, and then utilize the model to predict energy consumption and identify cost-effective retrofits under TMY weather conditions for San Juan, Puerto Rico.

\section{Buildings}

Building inventory data for Fort Buchanan were obtained from the Headquarters Executive Information System (HQEIS) databases. Twenty-eight building groups were developed to represent the Fort and each of the buildings at Fort Buchanan was assigned to one of the groups. The mean building size (square footage) and vintage (age) were then calculated for each group based on the building inventory specific to Fort Buchanan. Building characteristics were developed from a combination of inferencing relationships within the FEDS model (driven by building type, size, climate, and vintage), walk-through audits of selected buildings at Fort Buchanan, and additional building data collected while visiting the Fort.

\section{Central Energy Plants}

By definition, the FEDS model considers any boiler or chiller that provides heating or cooling to more than one building a central plant. The high school, middle school, and elementary school chillers fit this definition and were modeled as chilled water central energy plants (CEPs).

\section{Other Loads}

No comprehensive inventory of exterior lighting (including street lighting) was found, but the number of street lighting poles was estimated using data from a previous light pole replacement and numbering project. Using this data and the site staff's knowledge of type and wattage of bulbs typically used, the exterior lighting annual electric consumption was estimated at 186 MWh.

The estimated annual electricity consumption for water pumping (potable water, sewage, and pool water) was nearly $965 \mathrm{MWh}$. This estimate is based on pump size and utilization data collected during the site visit.

The golf cart battery charging station was estimated to use only 5.6 MWh annually, based on nameplate data and an interview with an employee.

Electricity distribution losses were assumed to be $4 \%$ of purchased electricity.

\section{Model Calibration}

Building energy use was simulated with FEDS and combined with the non-building energy infrastructure characterization to predict the total site energy consumption for FY 2003. Uncertain elements of the modeling assumptions were adjusted until the model's energy 
consumption prediction matched "reasonably well" with actual energy consumption for FY 2003. Specific model calibration results are shown below. ${ }^{1}$

\begin{tabular}{|l|l|c|}
\hline Model Element & \multicolumn{1}{|c|}{ Fuel Type } & Error* \\
\hline Commissary & Electric & $+2.1 \%$ \\
\hline Schools & Electric & $-2.5 \%$ \\
\hline Total by Fuel Type & Electric & $0.0 \%$ \\
\hline Total Energy & All & $0.0 \%$ \\
\hline $\begin{array}{l}\text { *Total electrical consumption was the only number that could } \\
\text { be accurately calibrated, due to incomplete metering and LPG } \\
\text { consumption data. Building electrical metered data was only } \\
\text { available for 5 months of FY 2003; therefore, electrical usage } \\
\text { for schools and the commissary was determined using a } \\
\text { partial year. A large percentage of error is expected here. } \\
\text { LPG consumption was missing completely for some } \\
\text { buildings, and was estimated for the rest, although this } \\
\text { represents a very small fraction of the total energy used, } \\
\text { primarily in food preparation. }\end{array}$ \\
\hline \multicolumn{2}{|l}{} \\
\hline
\end{tabular}

The model calibration includes the family housing units in Coconut Grove (30sf-2) and Coqui Gardens (30sf-3). Because these units were occupied during the calibration year (FY2003), they must be included for proper model calibration. After the site visit, however, major demolition has taken place in those two housing areas. For this reason, no retrofits will be allowed for 30sf2 and 30 sf- 3 .

\section{Description of Opportunities Identified}

The number of conceivable energy conservation measures and fuel-switching opportunities at federal sites is very large. The FEDS model is used to cost-effectively identify energy saving opportunities for the site. FEDS is a software tool that provides a comprehensive method to quickly and objectively identify energy improvements that offer maximum life-cycle cost savings. FEDS determines the optimum set of cost-effective retrofits from a current database of hundreds of proven technologies. These include retrofits for heating, cooling, lighting, motors, building envelope, and hot water systems. Interactive effects are also evaluated as part of the optimization process so that energy savings are not double counted or undercounted. The results are based on life-cycle cost economics consistent with 10 CFR 436.

FEDS identifies the package of retrofits that individually and collectively minimize the life-cycle cost of building energy services, resulting in projects where the net present value (NPV) of the investment is greater than or equal to zero and the savings-to-investment ratio (SIR) is greater than or equal to one. Results are developed for government (appropriated) and alternative (e.g., ESPC and UESC) financing assumptions.

\footnotetext{
${ }^{1}$ For example, an error of $+0.5 \%$ means that the model predicts energy consumption $0.5 \%$ higher than reported consumption.
} 
In general, the discount rate is higher and the economic evaluation life is shorter for alternative financing compared to government financing. The economic life for the latter is set at 25 years with the discount rate adjusted each year in response to market conditions. The FY03 prescribed government discount rate of is $3.0 \%$ in real terms, i.e., in excess of general inflation was used in the analysis. Alternative financing assumptions are not prescribed, but set by negotiation between the ESCO and the federal organization. An economic evaluation life of 15 years and a real discount rate of $5.38 \%$ are used to represent alternative financing conditions in this assessment, based on a collection of prior site experiences in the Army.

Table 2 summarizes the FEDS results by retrofit category (e.g., cooling) and type (e.g., chillers) using appropriated funding as the source of capital for the projects. Table 3 summarizes the FEDS results by retrofit category using alternative financing as the source of capital for the projects. The complete list of cost-effective energy- and cost-reduction projects resulting from the FEDS modeling and analysis are presented in Appendices C-1 (appropriated funds) and C-2 (alternative financing). ${ }^{2}$

Table 2. Summary of All Cost-Effective Projects Identified from the FEDS Assessment for Fort Buchanan Using Appropriated Source of Capital (by retrofit category and type)

\begin{tabular}{|c|c|c|c|c|c|c|c|}
\hline $\begin{array}{l}\text { Retrofit } \\
\text { Category }\end{array}$ & Retrofit Type & $\begin{array}{c}\text { Energy } \\
\text { Savings } \\
\text { (MMBtu/yr) }\end{array}$ & $\begin{array}{c}\text { 1st Year } \\
\text { Savings } \\
(\$ / y r)\end{array}$ & $\begin{array}{c}\text { Installed } \\
\text { Cost (\$) }\end{array}$ & $\begin{array}{c}\text { Net } \\
\text { Present } \\
\text { Value (\$) }\end{array}$ & SIR & $\begin{array}{c}\text { Simple } \\
\text { Payback } \\
\text { (yr) }\end{array}$ \\
\hline \multirow[t]{4}{*}{ Cooling } & Chillers & 4,890 & 157,542 & $1,428,730$ & 514,156 & 1.56 & 9.1 \\
\hline & Package AC Units & 182 & 10,697 & 77,515 & 104,715 & 3.89 & 7.2 \\
\hline & Window AC Units & 50 & 1,692 & 18,320 & 815 & 1.10 & 10.8 \\
\hline & Subtotal & 5,122 & 169,931 & $1,524,565$ & 619,686 & 1.64 & 9.0 \\
\hline \multirow{5}{*}{ Envelope } & Attic/Ceiling Insulation & 5,792 & 153,528 & 789,353 & $1,910,546$ & 3.38 & 5.1 \\
\hline & Foundation Insulation & 1,509 & 33,520 & 368,619 & 220,875 & 1.60 & 11.0 \\
\hline & Wall Insulation & 3,869 & 122,560 & 546,407 & $1,608,882$ & 4.36 & 4.5 \\
\hline & Windows & 1,011 & 32,048 & 270,002 & 293,574 & 2.11 & 8.4 \\
\hline & Subtotal & 12,181 & 341,656 & $1,974,381$ & $4,033,877$ & 3.11 & 5.8 \\
\hline \multirow{3}{*}{ Hot Water } & Misc. Measures & 536 & 11,997 & 9,617 & 151,612 & 27.24 & 0.8 \\
\hline & $\begin{array}{l}\text { Water Heaters with } \\
\text { Misc. Measures }\end{array}$ & 1,902 & 49,207 & 157,242 & 528,466 & 4.16 & 3.2 \\
\hline & Subtotal & 2,438 & 61,203 & 166,851 & $\mathbf{6 8 0 , 0 7 7}$ & 4.93 & 2.7 \\
\hline \multirow[t]{5}{*}{ Lights } & CFLs & 2,101 & 78,769 & 239,135 & $1,142,018$ & 5.72 & 3.0 \\
\hline & Exit Signs & 82 & 8,212 & 56,201 & 87,143 & 2.53 & 6.8 \\
\hline & HIDs & 1 & 182 & 1,829 & 1,343 & 1.70 & 10.0 \\
\hline & T-8s, other Fluorescents & 6,279 & 191,169 & $1,203,315$ & $2,154,460$ & 2.79 & 6.3 \\
\hline & Subtotal & 8,463 & 278,332 & $1,500,480$ & $3,384,964$ & 3.25 & 5.4 \\
\hline \multicolumn{2}{|l|}{ Grand Total } & 28,204 & 851,122 & $5,166,277$ & $8,718,604$ & 2.91 & 6.1 \\
\hline
\end{tabular}

\footnotetext{
${ }^{2}$ It should be noted that in addition to this report, the Fort Buchanan energy manager will also receive a CD-ROM, which includes all the FEDS input data and output project files. The input data files reflect information collected during the site visits and additional assumptions required to perform the FEDS modeling and assessment. The output project files contain significantly more detailed information to support the list of cost-effective energy projects identified in Appendices C-1 and C-2.
} 
From Table 2, the total cost-effective energy savings is estimated at 28,204 MMBtu/year representing \$851,000/year savings with an overall savings to investment ratio (SIR) of 2.91. This represents $15.7 \%$ in energy savings based on FY 2003 energy data.

The greatest energy saving potential was found in building envelope measures (12,181 MMBtu/year), followed by lighting (8,463 MMBtu/year). The largest estimated dollar savings was also building envelope ( $\$ 341,000 /$ year), again followed by lighting $(\$ 278,000 /$ year). Miscellaneous service hot water measures (although small projects) overwhelmingly show the greatest SIR (27.25), followed by compact fluorescent lighting (5.72).

Table 3. Summary of All Cost-Effective Projects Identified from the FEDS Assessment for Fort Buchanan Using Alternative Financing as the Source of Capital (by retrofit category and type)

\begin{tabular}{|c|c|c|c|c|c|c|c|}
\hline $\begin{array}{l}\text { Retrofit } \\
\text { Category }\end{array}$ & Retrofit Type & $\begin{array}{c}\text { Energy } \\
\text { Savings } \\
\text { (MMBtu/yr) }\end{array}$ & $\begin{array}{c}\text { 1st Year } \\
\text { Savings } \\
(\$ / y r)\end{array}$ & $\begin{array}{l}\text { Installed } \\
\text { Cost (\$) }\end{array}$ & $\begin{array}{c}\text { Net } \\
\text { Present } \\
\text { Value (\$) }\end{array}$ & SIR & $\begin{array}{c}\text { Simple } \\
\text { Payback } \\
\text { (yr) }\end{array}$ \\
\hline \multirow{3}{*}{ Cooling } & Chillers & 1,986 & 66,697 & 440,930 & 211,771 & 1.52 & 6.6 \\
\hline & Package AC Units & 159 & 9,785 & 70,312 & 153,656 & 3.20 & 7.2 \\
\hline & $\begin{array}{r}\text { Subtotal } \\
\end{array}$ & 2,145 & 76,482 & 511,242 & 365,427 & 1.77 & 6.7 \\
\hline \multirow[t]{5}{*}{ Envelope } & Attic/Ceiling Insulation & 4,487 & 130,603 & 509,314 & 800,639 & 2.63 & 3.9 \\
\hline & Foundation Insulation & 139 & 4,348 & 33,897 & 9,710 & 1.28 & 7.8 \\
\hline & Wall Insulation & 3,548 & 113,474 & 397,268 & 740,879 & 2.90 & 3.5 \\
\hline & Windows & 839 & 27,082 & 230,893 & 40,746 & 1.17 & 8.5 \\
\hline & Subtotal & 9,013 & 275,507 & $1,171,372$ & $1,591,974$ & 2.38 & 4.3 \\
\hline \multirow[t]{3}{*}{ Hot Water } & Misc. Measures & 978 & 19,752 & 5,722 & 207,440 & 37.3 & 0.3 \\
\hline & $\begin{array}{r}\text { Water Heaters with } \\
\text { Misc. Measures } \\
\end{array}$ & 1,199 & 37,151 & 104,244 & 253,871 & 3.12 & 2.8 \\
\hline & Subtotal & 2,177 & 56,903 & 109,966 & 461,311 & 4.68 & 1.9 \\
\hline \multirow[t]{5}{*}{ Lights } & CFLs & 2,078 & 78,703 & 228,486 & 563,045 & 3.75 & 2.9 \\
\hline & Exit Signs & 82 & 7,531 & 56,172 & 19,806 & 1.35 & 7.5 \\
\hline & HIDs & 1 & 204 & 1,829 & 227 & 1.10 & 9.0 \\
\hline & T-8s, other Fluorescents & 4,683 & 167,987 & 733,645 & 954,713 & 2.32 & 4.4 \\
\hline & Subtotal & 6,844 & 254,425 & $1,020,132$ & $1,537,791$ & 2.56 & 4.0 \\
\hline & "Grand Total & 20,179 & 663,317 & $2,812,712$ & $3,3,956,503$ & 2.45 & 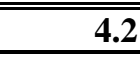 \\
\hline
\end{tabular}

From Table 3, the total cost-effective energy savings is estimated at 20,179 MMBtu/year representing $\$ 663,000 / y e a r$ savings with an overall SIR of 2.45 . This represents $11.2 \%$ in energy savings based on FY 2003 energy data.

The greatest energy saving potential was found in building envelope measures (9,013 MMBtu/year), followed by lighting (6,844 MMBtu/year.) The largest estimated dollar savings was envelope (\$275,000/year) followed by lighting ( $\$ 254,000 /$ year). Miscellaneous service hot water measures again show the far greatest SIR (37.31), followed by compact fluorescent lighting (3.75).

As would be expected, the total number of cost-effective retrofits is fewer (and installed cost/ capital investment is significantly less) under alternative financing source of capital, and thus the energy and dollar savings are likewise less. The total number of cost-effective retrofits using 
appropriated source of capital is 119 and the total number of cost-effective retrofits using alternative financing source of capital is 91. Using appropriated funding will save 8,025 MMBTU/year and $\$ 187,805 /$ year more than alternative financing. Utilizing alternative financing reduces the simple payback from 6.1 to 4.2 years because some projects with longer paybacks are eliminated under the alternative financing scenario.

The complete list of cost-effective energy- and cost-reduction projects is given Appendix C-1 for appropriated funds source of capital and in Appendix C-2 for alternative financing source of capital. $^{3}$

\section{Recommendations for More In-Depth Assessments}

The FEDS model can provide an unbiased assessment of literally hundreds of energy conservation projects; unfortunately, it is not all-inclusive. While the scope of this project is limited to energy-saving projects included in the FEDS model, the energy-saving opportunities identified below were recognized during the site visit and may be worth additional consideration by the site energy staff. It is recommended that the site consider additional assessment of these potential projects.

\section{Programmable Thermostats}

The FEDS model does not consider programmable thermostats in the energy analysis. Programmable thermostats are considered a conservation measure rather than an equipment replacement or building improvement. However, during the site visit, the team did not observe any programmable thermostats; although Fort Buchanan has procured several programmable thermostats for family housing quarters and is has them on schedule the gradual installation of them. Programmable thermostats could be a useful conservation measure in smaller commercial buildings, family housing, or any building that is unoccupied during part of the day.

\section{Humidity Control}

A consistent problem witnessed during the site visit was buildings over-cooled because of discomfort with humidity. For example, classrooms with dry-bulb temperatures in the 60's with doors and windows open (which brings in more moist air) presumably because the classrooms are too cold.

Fort Buchanan should take an active position on future construction and equipment replacement that considers dehumidification strategies in addition to temperature control. Because occupants can be comfortable in warmer, dry air, this will help save money, avoid over-cooled buildings, and increase occupant comfort levels.

\footnotetext{
${ }^{3}$ The Fort Buchanan energy manager will also receive a CD-ROM, which includes all the FEDS input data and output project files. The input data files reflect information collected during the site visits and additional assumptions required to perform the FEDS modeling and assessment.
} 
Possible solutions to humidity control that Fort Buchanan should consider and/or actively promote include:

- Verify (commission) temperature settings along all primary facilities to ensure these are operating to the optimum level possible.

- Installation of variable air volume (VAV) boxes in schools (may be a potential solution if that is the reason for over-cooled classrooms)

- Consider the use of desiccant wheel dehumidification on larger buildings and new construction.

- Consider heat-pipe or other "wrap-around" pre-cooling/reheat devices which remove moisture from the air.

\section{Additional Envelope Measures}

The FEDS model identified many envelope-related measures (e.g., window replacement, additional insulation) as cost-effective retrofits. While insulation and windows may not be immediately obvious, consider that the Fort is now cooling buildings that were originally built to be cooled by natural air movement. Furthermore, attacking infiltration (primarily through window replacement) will aid in the fight to reduce indoor humidity levels. Fort Buchanan DPW should support good envelope measures in future building retrofits and avoid at all cost the practice of putting plastic over open-air hurricane louvers and installing air-conditioning. 


\section{Appendix A \\ FEDS Data Collection Form}

The following form is used to collect FEDS input data during building audits. Note that not all data types indicated on this form are applicable to all buildings. Nor is all the information indicated on this form always available. Where necessary, the FEDS model infers the values for missing data based on other known building characteristics.

FEDS Building Information for

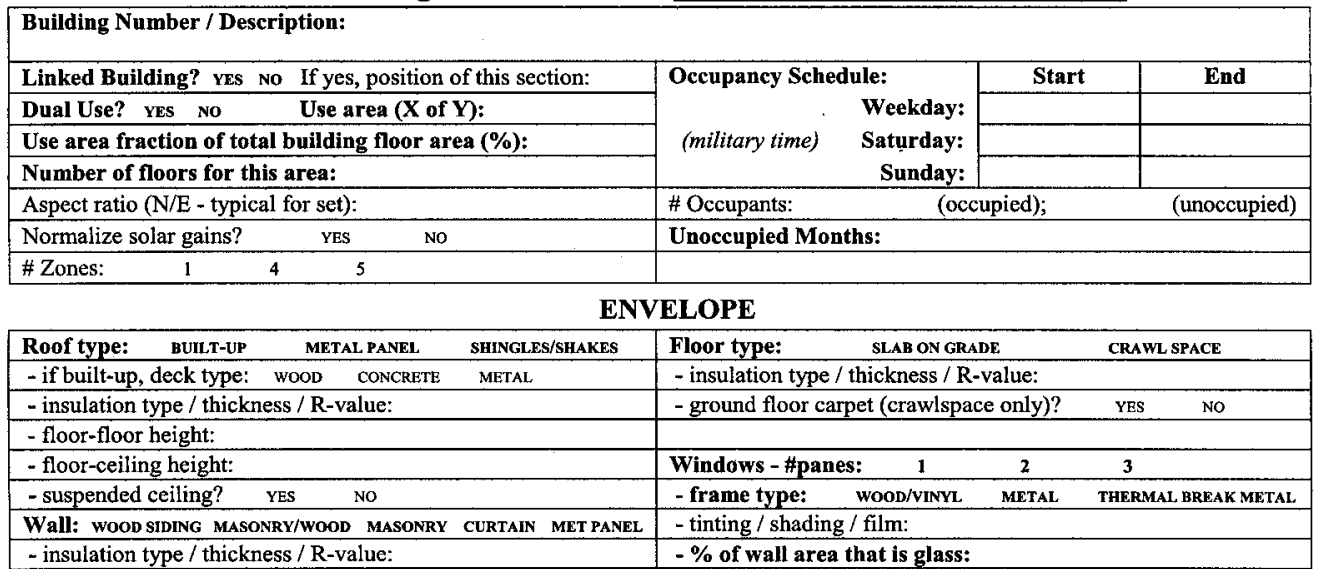

LIGHTING

\begin{tabular}{|l|l|l|l|l|l|}
\hline $\begin{array}{c}\text { Technology } \\
\text { Type }\end{array}$ & $\begin{array}{l}\text { Fixture Description (type, size, \#lamps, } \\
\text { wattage, ballasts, location/application, etc.) }\end{array}$ & $\begin{array}{c}\text { \% of area served } \\
\text { (or fixture count) }\end{array}$ & $\begin{array}{c}\text { Mounting } \\
\text { Method }\end{array}$ & $\begin{array}{c}\text { Occupied } \\
\text { Utilization \% }\end{array}$ & $\begin{array}{c}\text { Unoccupied } \\
\text { Utilization \% }\end{array}$ \\
\hline & & & & & \\
\hline & & & & & \\
\hline & & & & & \\
\hline & & & & & \\
\hline & & & & & \\
\hline & & & & & \\
\hline
\end{tabular}

SERVICE HOT WATER

\begin{tabular}{|c|c|c|c|}
\hline $\begin{array}{l}\text { Portion of building set served (whole buildings) } \\
\text { ( } \mathrm{ft}^{2}, \%, \text { or \# of bldgs.) }\end{array}$ & System 1: & System 2: & System 3: \\
\hline \multicolumn{4}{|l|}{ Fuel type } \\
\hline System type & DISTRIBUTED & DISTRIBUTED & DISTRIBUTED \\
\hline \multicolumn{4}{|l|}{ Equipment vintage } \\
\hline \multicolumn{4}{|l|}{ Tank capacity (gallons, \#tanks) } \\
\hline \multicolumn{4}{|l|}{ Efficiency } \\
\hline \multicolumn{4}{|l|}{ Thermostat set point, ${ }^{\circ} \mathrm{F}$} \\
\hline Tank insulation - thickness/R-value & & 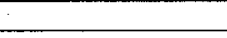 & \\
\hline \multicolumn{4}{|l|}{ Heating capacity (loop only) } \\
\hline \multicolumn{4}{|l|}{ Loop length (perimeter or stacked service) } \\
\hline \multicolumn{4}{|l|}{ \#Faucets / aerators installed (\%) } \\
\hline \multicolumn{4}{|l|}{ \#Showers / low-flow showerheads installed (\%) } \\
\hline $\begin{array}{l}\text { Note presence of: bottom boards, near tank pipe } \\
\text { insul., tank wrap, heat traps, electronic pilots }\end{array}$ & & & \\
\hline
\end{tabular}

Auditor:

Sheet of

Date: 
HVAC

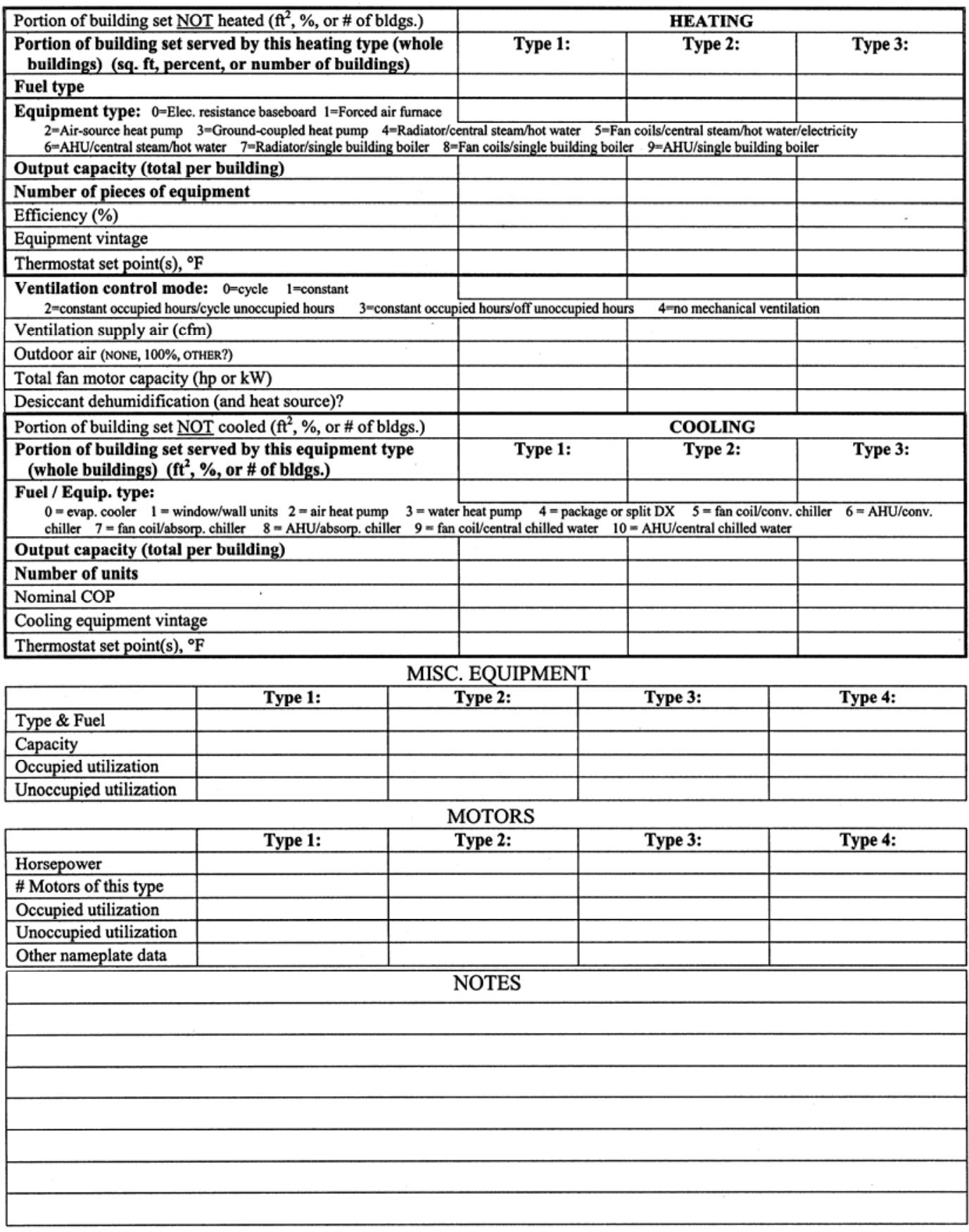




\section{Appendix B \\ Facility Category Descriptions and Associated Buildings}

The following table identifies the buildings in the facility categories defined by the assessment team. The table below also includes the FEDS facility category code, the proxy building number(s) audited for the purpose of developing the FEDS model, the proxy building total square footage, the total number of buildings in the category, the total square footage in that category and the $\%$ of square footage represented by the proxy buildings.

\begin{tabular}{|c|c|c|c|c|c|}
\hline $\begin{array}{l}\text { Category Description [FEDS } \\
\text { Facility Category Code] }\end{array}$ & $\begin{array}{c}\text { Proxy Building } \\
\text { Number }\end{array}$ & $\begin{array}{l}\text { Proxy Building } \\
\text { (sq. ft) }\end{array}$ & $\begin{array}{l}\text { Total Bldgs. in } \\
\text { Category }\end{array}$ & $\begin{array}{l}\text { Total Sq. Ft. in } \\
\text { Category }\end{array}$ & $\begin{array}{c}\text { Proxy Sq. Ft. \% of } \\
\text { Category }\end{array}$ \\
\hline \multirow[t]{15}{*}{ Overhead Protection [1] } & 179 & 2637 & 64 & 17,753 & $14.9 \%$ \\
\hline & \multicolumn{5}{|c|}{ Buildings in this Category } \\
\hline & 16 & 165 & 352 & 398 & 1089 \\
\hline & 22 & 179 & 366 & 558 & 1090 \\
\hline & 31 & 182 & 367 & 570 & 1091 \\
\hline & 36 & 184 & 370 & 579 & 1092 \\
\hline & 65 & 185 & 371 & 625 & 1093 \\
\hline & 68 & 191 & 377 & 626 & 1098 \\
\hline & 71 & 198 & 378 & 674 & 1291 \\
\hline & 120 & 234 & 379 & 800 & 1293 \\
\hline & 139 & 237 & 383 & 834 & 1295 \\
\hline & 153 & 255 & 384 & 835 & 1299 \\
\hline & 154 & 267 & 389 & 998 & S1300 \\
\hline & 156 & 293 & 396 & 999 & S1301 \\
\hline & 158 & 351 & 397 & 1088 & \\
\hline \multirow{4}{*}{$\begin{array}{l}\text { Administration with Storage } \\
\text { [10a] }\end{array}$} & 509 & 10,000 & 7 & 57,072 & $17.5 \%$ \\
\hline & \multicolumn{5}{|c|}{ Buildings in this Category } \\
\hline & 504 & 509 & 514 & 551 & 1313 \\
\hline & 507 & 511 & & & \\
\hline \multirow{3}{*}{$\begin{array}{l}\text { Administration with Storage } \\
\text { \& Maintenance [10b] }\end{array}$} & 556 & 54,879 & 1 & 54,879 & $100.0 \%$ \\
\hline & \multicolumn{5}{|c|}{ Buildings in this Category } \\
\hline & 556 & & & & \\
\hline \multirow[t]{6}{*}{ Training Centers [10c] } & 1305 & 8785 & 17 & 152,725 & $5.8 \%$ \\
\hline & \multicolumn{5}{|c|}{ Buildings in this Category } \\
\hline & 522 & 1306 & 1311 & 1318 & 1322 \\
\hline & 523 & 1307 & 1312 & 1319 & 1323 \\
\hline & 525 & 1308 & 1316 & 1320 & 1324 \\
\hline & 1305 & 1310 & & & \\
\hline \multirow{7}{*}{$\begin{array}{l}\text { Smaller 1940s General } \\
\text { Purpose Administration } \\
\text { [10d] }\end{array}$} & 225 & 2482 & 24 & 94,232 & $2.6 \%$ \\
\hline & \multicolumn{5}{|c|}{ Buildings in this Category } \\
\hline & 176 & 212 & 224 & 233 & 1303 \\
\hline & 177 & 218 & 225 & 376 & 1304 \\
\hline & 192 & 219 & 227 & 518 & 1314 \\
\hline & 193 & 220 & 228 & 746 & 1317 \\
\hline & 206 & 223 & 231 & 1302 & \\
\hline
\end{tabular}




\begin{tabular}{|c|c|c|c|c|c|}
\hline $\begin{array}{l}\text { Category Description [FEDS } \\
\text { Facility Category Code] }\end{array}$ & $\begin{array}{c}\text { Proxy Building } \\
\text { Number }\end{array}$ & $\begin{array}{l}\text { Proxy Building } \\
\text { (sq. ft) }\end{array}$ & $\begin{array}{l}\text { Total Bldgs. in } \\
\text { Category }\end{array}$ & $\begin{array}{l}\text { Total Sq. Ft. in } \\
\text { Category }\end{array}$ & \begin{tabular}{|c|} 
Proxy Sq. Ft. \% of \\
Category
\end{tabular} \\
\hline \multirow{4}{*}{$\begin{array}{l}\text { Larger 1940s General } \\
\text { Purpose Administration } \\
\text { [10e] }\end{array}$} & 152; 390; 399 & $\begin{array}{c}10,084 ; 29,014 \\
18,047\end{array}$ & 6 & 99,228 & $57.6 \%$ \\
\hline & \multicolumn{5}{|c|}{ Buildings in this Category } \\
\hline & 152 & 399 & 512 & 566 & 607 \\
\hline & 390 & & & & \\
\hline \multirow{8}{*}{$\begin{array}{l}\text { 1950s \& 60s General } \\
\text { Purpose Administration } \\
{[10 f]}\end{array}$} & 203 & 2775 & 28 & 70,258 & $3.9 \%$ \\
\hline & \multicolumn{5}{|c|}{ Buildings in this Category } \\
\hline & 28 & 348 & 1022 & 1106 & 1143 \\
\hline & 67 & 1017 & 1101 & 1107 & 1144 \\
\hline & 202 & 1018 & 1102 & 1140 & 1145 \\
\hline & 203 & 1019 & 1103 & 1141 & 1146 \\
\hline & 204 & 1020 & 1104 & 1142 & 1147 \\
\hline & 214 & 1021 & 1105 & & \\
\hline \multirow{4}{*}{$\begin{array}{l}\text { Newer General Purpose } \\
\text { Administration [10g] }\end{array}$} & 540 & 11,942 & 9 & 38,685 & $30.9 \%$ \\
\hline & \multicolumn{5}{|c|}{ Buildings in this Category } \\
\hline & 23 & 136 & 501 & 576 & 673 \\
\hline & 25 & 292 & 540 & 665 & \\
\hline \multirow[t]{9}{*}{ School Trailers [10tr] } & 92; 1066 & 1655; 2421 & 34 & 47,346 & $8.6 \%$ \\
\hline & \multicolumn{5}{|c|}{ Buildings in this Category } \\
\hline & 13 & 89 & 96 & 1049 & 1070 \\
\hline & 15 & 90 & 97 & 1050 & 1072 \\
\hline & 18 & 91 & 99 & 1051 & 1074 \\
\hline & 19 & 92 & 1034 & 1052 & 1095 \\
\hline & 30 & 93 & 1046 & 1053 & 1096 \\
\hline & 87 & 94 & 1047 & 1054 & 1097 \\
\hline & 88 & 95 & 1048 & 1066 & \\
\hline \multirow[t]{5}{*}{ Intermediate School [10is] } & 78 & 2714 & 12 & 49,020 & $5.5 \%$ \\
\hline & \multicolumn{5}{|c|}{ Buildings in this Category } \\
\hline & 73 & 77 & 80 & 82 & 84 \\
\hline & 74 & 78 & 81 & 83 & 85 \\
\hline & 75 & 79 & & & \\
\hline \multirow[t]{5}{*}{ Elementary School [10es] } & 1031 & 4055 & 13 & 55,473 & $7.3 \%$ \\
\hline & \multicolumn{5}{|c|}{ Buildings in this Category } \\
\hline & 1029 & 1032 & 1037 & 1040 & 1042 \\
\hline & 1030 & 1033 & 1038 & 1041 & 1043 \\
\hline & 1031 & 1035 & 1039 & & \\
\hline \multirow[t]{4}{*}{ Middle School [10ms] } & 1073 & 8466 & 9 & 73,485 & $11.5 \%$ \\
\hline & \multicolumn{5}{|c|}{ Buildings in this Category } \\
\hline & 1071 & 1075 & 1079 & 1083 & 1094 \\
\hline & 1073 & 1077 & 1081 & 1085 & \\
\hline \multirow[t]{3}{*}{ High School [10hs] } & 1062 & 54,064 & 3 & 80,392 & $67.3 \%$ \\
\hline & \multicolumn{5}{|c|}{ Buildings in this Category } \\
\hline & 1060 & 1062 & 1068 & & \\
\hline \multirow[t]{4}{*}{ Clinics [21] } & 21 & 13,575 & 6 & 23,513 & $57.7 \%$ \\
\hline & \multicolumn{5}{|c|}{ Buildings in this Category } \\
\hline & 21 & 295 & 312 & 670 & 676 \\
\hline & 291 & & & & \\
\hline
\end{tabular}




\begin{tabular}{|c|c|c|c|c|c|}
\hline $\begin{array}{l}\text { Category Description [FEDS } \\
\text { Facility Category Code] }\end{array}$ & $\begin{array}{l}\text { Proxy Building } \\
\text { Number }\end{array}$ & $\begin{array}{l}\text { Proxy Building } \\
\text { (sq. ft) }\end{array}$ & $\begin{array}{l}\text { Total Bldgs. in } \\
\text { Category }\end{array}$ & $\begin{array}{l}\text { Total Sq. Ft. in } \\
\text { Category }\end{array}$ & $\begin{array}{c}\text { Proxy Sq. Ft. \% of } \\
\text { Category }\end{array}$ \\
\hline \multirow[t]{3}{*}{ Older Barracks [30b-1] } & 1300; 1301 & 8814; 8814 & $\mathbf{5}$ & 47,411 & $37.2 \%$ \\
\hline & \multicolumn{5}{|c|}{ Buildings in this Category } \\
\hline & 119 (Demolished) & 1232 & 1300 & 1301 & 1315 \\
\hline \multirow[t]{3}{*}{2000 Army Lodging [30b-2] } & 678 & 36,372 & 4 & 54,526 & $66.7 \%$ \\
\hline & \multicolumn{5}{|c|}{ Buildings in this Category } \\
\hline & 678 & 679 & 680 & 681 & \\
\hline \multirow[t]{8}{*}{ Las Colinas [30sf-1] } & 807; 815 & $2947 ; 2448$ & 29 & $\mathbf{7 5 , 9 2 9}$ & $7.1 \%$ \\
\hline & \multicolumn{5}{|c|}{ Buildings in this Category } \\
\hline & 803 & 809 & 815 & 821 & 827 \\
\hline & 804 & 810 & 816 & 822 & 828 \\
\hline & 805 & 811 & 817 & 823 & 829 \\
\hline & 806 & 812 & 818 & 824 & 830 \\
\hline & 807 & 813 & 819 & 825 & 831 \\
\hline & 808 & 814 & 820 & 826 & \\
\hline \multirow[t]{28}{*}{ Coconut Grove [30sf-2] ${ }^{4}$} & 1134 & 1209 & 127 & 168,780 & $0.7 \%$ \\
\hline & \multicolumn{5}{|c|}{ Buildings in this Category } \\
\hline & 801 & 1132 & 1166 & 1191(Demolished) & 1216(Demolished) \\
\hline & 802 & 1133(Demolished) & 1167 & 1192 & 1217 \\
\hline & 1108(Demolished) & 1134 & 1168 & 1193 & 1218(Demolished) \\
\hline & 1109 & 1135 & 1169(Demolished) & 1194(Demolished) & 1219 \\
\hline & 1110(Demolished) & 1136(Demolished) & 1170 & 1195(Demolished) & 1220(Demolished) \\
\hline & 1111(Demolished) & 1137 & 1171(Demolished) & 1196(Demolished) & 1221(Demolished) \\
\hline & 1112 & 1138 & 1172(Demolished) & 1197 & 1222(Demolished) \\
\hline & 1113(Demolished) & 1139 & 1173 & 1198 & 1223 \\
\hline & 1114(Demolished) & 1148(Demolished) & 1174 & 1199 & 1224(Demolished) \\
\hline & 1115 & 1149 & 1175(Demolished) & 1200(Demolished) & 1225(Demolished) \\
\hline & 1116(Demolished) & 1150(Demolished) & 1176 & 1201(Demolished) & 1226 \\
\hline & 1117 & 1151(Demolished) & 1177(Demolished) & 1202(Demolished) & 1227(Demolished) \\
\hline & 1118 & 1152 & 1178(Demolished) & 1203 & 1228(Demolished) \\
\hline & 1119(Demolished) & 1153(Demolished) & 1179 & 1204 & 1229 \\
\hline & 1120(Demolished) & 1154 & 1180(Demolished) & 1205 & 1230(Demolished) \\
\hline & 1121(Demolished) & 1155 & 1181 & 1206(Demolished) & 1231 \\
\hline & 1122 & 1156(Demolished) & 1182 & 1207 & 1233(Demolished) \\
\hline & 1123(Demolished) & 1157(Demolished) & 1183(Demolished) & 1208 & 1234 \\
\hline & 1124(Demolished) & 1158 & 1184 & 1209(Demolished) & 1235 \\
\hline & 1125 & 1159(Demolished) & 1185 & 1210 & 1236(Demolished) \\
\hline & 1126(Demolished) & 1160(Demolished) & 1186(Demolished) & 1211 & 1237 \\
\hline & 1127 & 1161 & 1187 & 1212(Demolished) & 1238(Demolished) \\
\hline & 1128(Demolished) & 1162 & 1188(Demolished) & 1213(Demolished) & 1239 \\
\hline & 1129 & 1163 & 1189(Demolished) & 1214 & 1240(Demolished) \\
\hline & 1130(Demolished) & 1164(Demolished) & 1190 & 1215 & 1241 \\
\hline & 1131(Demolished) & 1165(Demolished) & & & \\
\hline
\end{tabular}

\footnotetext{
${ }^{4}$ The model calibration includes the family housing units in Coconut Grove (30sf-2) and Coqui Gardens (30sf-3). These units existing during the calibration year and must be included for proper model calibration. After the site visit, major demolition has taken place in those two housing areas. For this reason, no retrofits will be allowed for 30 sf- 2 and 30 sf- 3 .
} 


\begin{tabular}{|c|c|c|c|c|c|}
\hline \begin{tabular}{|l|} 
Category Description [FEDS \\
Facility Category Code]
\end{tabular} & $\begin{array}{c}\text { Proxy Building } \\
\text { Number }\end{array}$ & $\begin{array}{l}\text { Proxy Building } \\
\text { (sq. ft) }\end{array}$ & $\begin{array}{l}\text { Total Bldgs. in } \\
\text { Category }\end{array}$ & $\begin{array}{l}\text { Total Sq. Ft. in } \\
\text { Category }\end{array}$ & \begin{tabular}{|c|} 
Proxy Sq. Ft. \% of \\
Category
\end{tabular} \\
\hline \multirow[t]{12}{*}{ Coqui Gardens $[30 \text { sf-3 } 3]^{4}$} & 1280 & 2244 & 48 & 109,328 & $2.1 \%$ \\
\hline & \multicolumn{5}{|c|}{ Buildings in this Category } \\
\hline & 1243 & 1253 & 1263 & 1273 & 1282 \\
\hline & 1244 & 1254 & 1264(Demolished) & 1274 & 1283 \\
\hline & 1245 & 1255 & 1265 & 1275 & 1284 \\
\hline & 1246 & 1256 & 1266(Demolished) & 1276 & 1285 \\
\hline & 1247 & 1257 & 1267 & 1277 & 1286 \\
\hline & 1248 & 1258(Demolished) & 1268(Demolished) & 1278 & 1287 \\
\hline & 1249 & 1259 & 1269 & 1279 & 1288 \\
\hline & 1250 & 1260(Demolished) & 1270(Demolished) & 1280 & 1289 \\
\hline & 1251(Demolished) & 1261 & 1271 & 1281 & 1290 \\
\hline & 1252 & 1262(Demolished) & 1272 & & \\
\hline \multirow[t]{6}{*}{ Buchanan Heights [30sf-4] } & 1011 & 4290 & 20 & 94,985 & $4.5 \%$ \\
\hline & \multicolumn{5}{|c|}{ Buildings in this Category } \\
\hline & 1000 & 1004 & 1008 & 1012 & 1016 \\
\hline & 1001 & 1005 & 1009 & 1013 & 1023 \\
\hline & 1002 & 1006 & 1010 & 1014 & 1024 \\
\hline & 1003 & 1007 & 1011 & 1015 & 1026 \\
\hline \multirow[t]{3}{*}{ Cold Storage [40a] } & 517 & 17,171 & 1 & 17,171 & $100.0 \%$ \\
\hline & \multicolumn{5}{|c|}{ Buildings in this Category } \\
\hline & 517 & & & & \\
\hline \multirow[t]{4}{*}{ 1940s Storage [40b] } & 614 & 20,468 & 9 & 100,640 & $20.3 \%$ \\
\hline & \multicolumn{5}{|c|}{ Buildings in this Category } \\
\hline & 180 & 527 & 563 & 612 & 1309 \\
\hline & 521 & 539 & 608 & 614 & \\
\hline \multirow[t]{3}{*}{ Large Storage [40c] } & 541 & 50,250 & 1 & 50,250 & $100.0 \%$ \\
\hline & \multicolumn{5}{|c|}{ Buildings in this Category } \\
\hline & 541 & & & & \\
\hline \multirow[t]{3}{*}{ Vehicle Maintenance [50] } & 528 & 10,089 & 1 & 10,089 & $100.0 \%$ \\
\hline & \multicolumn{5}{|c|}{ Buildings in this Category } \\
\hline & 528 & & & & \\
\hline \multirow[t]{3}{*}{ Commissary / PX [60a] } & 689 & 211,143 & 1 & 211,143 & $100.0 \%$ \\
\hline & \multicolumn{5}{|c|}{ Buildings in this Category } \\
\hline & 689 & & & & \\
\hline \multirow[t]{3}{*}{ Exchange / Security [60b] } & 613 & 20,468 & 5 & 101,565 & $20.2 \%$ \\
\hline & \multicolumn{5}{|c|}{ Buildings in this Category } \\
\hline & 606 & 611 & 613 & 1242 & 1321 \\
\hline \multirow[t]{4}{*}{ Dining [60c] } & 660 & 40,329 & 7 & 82,925 & $48.6 \%$ \\
\hline & \multicolumn{5}{|c|}{ Buildings in this Category } \\
\hline & 76 & 151 & 1036 & 1064 & 1087 \\
\hline & 98 & 660 & & & \\
\hline \multirow[t]{6}{*}{ Miscellaneous MWR [80] } & $148 ; 167 ; 168$ & $\begin{array}{l}\text { 7761; 17,000; } \\
20,780\end{array}$ & 20 & 83,109 & $54.8 \%$ \\
\hline & \multicolumn{5}{|c|}{ Buildings in this Category } \\
\hline & 69 & 161 & 171 & 313 & 387 \\
\hline & 138 & 166 & 172 & 380 & 395 \\
\hline & 148 & 167 & 181 & 381 & 519 \\
\hline & 159 & 168 & 183 & 386 & 1025 \\
\hline
\end{tabular}




\section{Appendix C-1 \\ Comprehensive List of Cost-Effective Projects Identified from the FEDS Assessment Using Appropriated Source of Capital}

The following table identifies the 119 cost-effective energy- and cost-reducing retrofit projects identified from the FEDS modeling and analysis based on the assumption that the projects will be funded using appropriated source of capital funds. Key energy and economic results are presented for each cost-effective retrofit measure. The projects are grouped by building category. More detail, supporting each line-item project recommendation, is contained in the FEDS input and output files, which are delivered to the site energy manager on a CD in conjunction with this report. 


\begin{tabular}{|c|c|c|c|c|c|c|c|}
\hline FEDS Category & Technology Change & \begin{tabular}{|c|} 
Energy \\
Savings \\
$($ MMBtu/yr) \\
\end{tabular} & $\begin{array}{c}\text { Annual } \\
\text { Savings } \\
(\$ / y r)\end{array}$ & $\begin{array}{c}\text { Capital Cost } \\
(\$)\end{array}$ & $\begin{array}{l}\text { Net Present } \\
\text { Value } \\
\text { (\$) }\end{array}$ & SIR & $\begin{array}{c}\text { Simple } \\
\text { Payback (yr) }\end{array}$ \\
\hline \multirow[t]{2}{*}{1} & $\begin{array}{l}\text { Replace 40-watt T-12 Lamps and Magnetic Ballasts with 32-watt } \\
\text { T-8 Lamps and Electronic Ballasts }\end{array}$ & 120 & 4,792 & 37,327 & 46,708 & 2.23 & 7.8 \\
\hline & Subtotal & 120 & 4,792 & 37,327 & 46,708 & 2.23 & 7.8 \\
\hline \multirow[t]{3}{*}{ 10a } & $\begin{array}{l}\text { Increase Attic Insulation by R-19 from R-5 to R-24 with Blow-In } \\
\text { Insulation }\end{array}$ & 208 & 7,965 & 30,431 & 109,640 & 4.60 & 3.8 \\
\hline & $\begin{array}{l}\text { Replace 2-watt LED Exit Signs with 0.2-watt Electroluminescent } \\
\text { Exit Signs }\end{array}$ & 4 & 482 & 3,442 & 4,952 & 2.40 & 7.1 \\
\hline & Subtotal & 212 & 8,447 & 33,873 & 114,592 & 4.37 & 4.0 \\
\hline \multirow[t]{7}{*}{ 10b1 } & $\begin{array}{l}\text { Increase Attic Insulation by R-13 from R-5 to R-18 with Blow-In } \\
\text { Insulation }\end{array}$ & 75 & 2,347 & 16,041 & 25,243 & 2.60 & 6.8 \\
\hline & $\begin{array}{l}\text { Replace 2-watt LED Exit Signs with 0.35-watt Electroluminescent } \\
\text { Exit Signs }\end{array}$ & 0 & 66 & 503 & 652 & 2.30 & 7.6 \\
\hline & $\begin{array}{l}\text { Replace 40-watt T-12 Lamps and Magnetic Ballasts with 32-watt } \\
\text { T-8 Lamps and Electronic Ballasts } \\
\end{array}$ & 47 & 2,353 & 18,125 & 23,138 & 2.30 & 7.7 \\
\hline & $\begin{array}{l}\text { Replace 40-watt T-12 Lamps and Magnetic Ballasts with 32-watt } \\
\text { T-8 Lamps and Electronic Ballasts with Reflectors }\end{array}$ & 136 & 5,258 & 32,314 & 60,029 & 2.90 & 6.1 \\
\hline & $\begin{array}{l}\text { Replace Existing Air-Cooled Electric Chiller (COP=2.53) with Very } \\
\text { High Efficiency Water-Cooled Reciprocating Electric Chiller } \\
(\mathrm{COP}=4.2) \text { and Cooling Tower }\end{array}$ & 65 & 2,614 & 22,588 & 9,057 & 1.70 & 8.6 \\
\hline & $\begin{array}{l}\text { Wrap Electric Hot Water Tank with R-11 Fiberglass Batt Insulation; } \\
\text { Insulate Pipes Near Tank; Install Low-Flow Showerheads to Reduce } \\
\text { Water Flow from 4.8 GPM to 2.0 GPM; Install Faucet Aerators }\end{array}$ & 3 & 110 & 348 & 465 & 4.67 & 3.2 \\
\hline & Subtotal & 326 & 12,748 & 89,919 & 118,584 & 2.51 & 7.1 \\
\hline \multirow[t]{6}{*}{$10 \mathrm{~b} 2$} & Increase Insulation in Suspended Ceiling by R-11 from R-7 to R-18 & 16 & 630 & 10,910 & 171 & 1.02 & 17.3 \\
\hline & $\begin{array}{l}\text { Replace 100-watt Metal Halide Lamps with 100-watt High Pressure } \\
\text { Sodium Lamps }\end{array}$ & 1 & 182 & 1,829 & 1,343 & 1.70 & 10.0 \\
\hline & $\begin{array}{l}\text { Replace 2-watt LED Exit Signs with 0.35-watt Electroluminescent } \\
\text { Exit Signs }\end{array}$ & 0 & 34 & 252 & 335 & 2.30 & 7.4 \\
\hline & $\begin{array}{l}\text { Replace 40-watt T-12 Lamps and Magnetic Ballasts with 32-watt } \\
\text { T-8 Lamps and Electronic Ballasts with Reflectors }\end{array}$ & 28 & 1,129 & 5,934 & 13,886 & 3.30 & 5.3 \\
\hline & $\begin{array}{l}\text { Wrap Electric Hot Water Tank with R-11 Fiberglass Batt Insulation; } \\
\text { Insulate Pipes Near Tank; Install Faucet Aerators }\end{array}$ & 2 & 58 & 162 & 256 & 5.36 & 2.8 \\
\hline & Subtotal & 47 & 2,033 & 19,087 & 15,991 & 1.83 & 9.4 \\
\hline
\end{tabular}




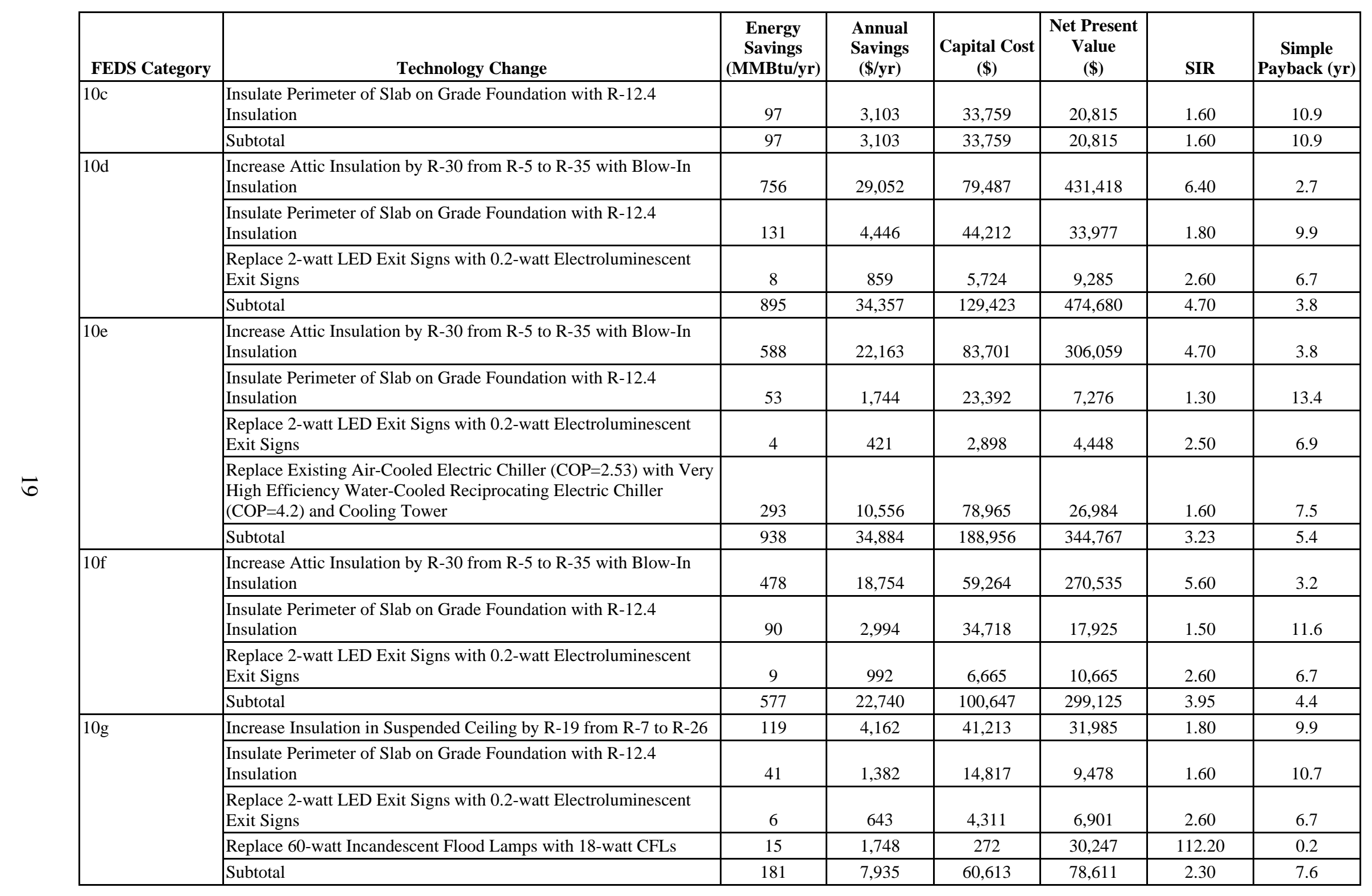




\begin{tabular}{|c|c|c|c|c|c|c|c|}
\hline FEDS Category & Technology Change & $\begin{array}{c}\text { Energy } \\
\text { Savings } \\
(\text { MMBtu/yr) }\end{array}$ & $\begin{array}{c}\text { Annual } \\
\text { Savings } \\
(\$ / y r)\end{array}$ & $\begin{array}{c}\text { Capital Cost } \\
(\$)\end{array}$ & $\begin{array}{l}\text { Net Present } \\
\text { Value } \\
\text { (\$) }\end{array}$ & SIR & $\begin{array}{c}\text { Simple } \\
\text { Payback (yr) }\end{array}$ \\
\hline \multirow[t]{7}{*}{$10 \operatorname{tr}$} & $\begin{array}{l}\text { Add Blow-in Wall Insulation to Fill Available Space, from R-0 to } \\
\text { R-22.2 }\end{array}$ & 3,562 & 113,636 & 397,268 & $1,601,093$ & 5.00 & 3.5 \\
\hline & $\begin{array}{l}\text { Increase Attic Insulation by R-30 from R-5 to R-35 with Blow-In } \\
\text { Insulation }\end{array}$ & 517 & 16,465 & 39,938 & 249,602 & 7.20 & 2.4 \\
\hline & $\begin{array}{l}\text { Replace 40-watt T-12 Lamps and Magnetic Ballasts with 32-watt } \\
\text { T-8 Lamps and Electronic Ballasts with Reflectors }\end{array}$ & 637 & 26,460 & 157,523 & 307,106 & 2.90 & 6.0 \\
\hline & Replace 75-watt Incandescent Flood Lamps with 23-watt CFLs & 42 & 3,295 & 653 & 56,914 & 88.20 & 0.2 \\
\hline & $\begin{array}{l}\text { Replace Existing Electric Package AC Unit }(\mathrm{COP}=2.52) \text { with Small } \\
\text { Single-Zone Packaged AC Unit }(\mathrm{COP}=3.57)\end{array}$ & 154 & 9,701 & 67,503 & 104,434 & 4.00 & 7.0 \\
\hline & $\begin{array}{l}\text { Replace Existing Metal Frame, Single Pane Windows with } \\
\text { Aluminum Frame, Double Pane, Argon-Filled Windows with Super } \\
\text { Low-e Film and Thermal Breaks }\end{array}$ & 155 & 4,549 & 46,696 & 33,298 & 1.70 & 10.3 \\
\hline & Subtotal & 5,067 & 174,106 & 709,581 & $2,352,447$ & 4.43 & 4.1 \\
\hline \multirow[t]{7}{*}{ 10is } & Add R-12.4 Interior Masonry Surface Wall Insulation & 307 & 8,924 & 149,139 & 7,789 & 1.10 & 16.7 \\
\hline & $\begin{array}{l}\text { Increase Roof Insulation by R-38 from R-5 to R-43 Above } \\
\text { Suspended Ceiling }\end{array}$ & 367 & 11,216 & 82,245 & 114,986 & 2.40 & 7.3 \\
\hline & $\begin{array}{l}\text { Insulate Perimeter of Slab on Grade Foundation with R-12.4 } \\
\text { Insulation }\end{array}$ & 107 & 3,161 & 20,412 & 35,179 & 2.70 & 6.5 \\
\hline & $\begin{array}{l}\text { Replace 300-watt Incandescent Lamps with Fluorescent Fixtures } \\
\text { Including 2x4 3-bulb 32-watt T-8 Lamps and Electronic Ballasts }\end{array}$ & 33 & 1,486 & 4,293 & 21,784 & 6.10 & 2.9 \\
\hline & $\begin{array}{l}\text { Replace 40-watt T-12 Lamps and Magnetic Ballasts with 32-watt } \\
\text { T-8 Lamps and Electronic Ballasts with Reflectors }\end{array}$ & 549 & 21,923 & 125,456 & 259,628 & 3.10 & 5.7 \\
\hline & $\begin{array}{l}\text { Replace Existing Metal Louvers and Plastic Windows with } \\
\text { Aluminum Frame, Double Pane, Argon-Filled Windows with Super } \\
\text { Low-e Film and Thermal Breaks }\end{array}$ & 856 & 27,499 & 223,306 & 260,276 & 2.20 & 8.1 \\
\hline & Subtotal & 2,219 & 74,209 & 604,851 & 699,642 & 2.33 & 8.2 \\
\hline \multirow[t]{6}{*}{$10 \mathrm{es}$} & Increase Insulation in Suspended Ceiling by R-19 from R-5 to R-24 & 514 & 6,644 & 59,098 & 57,738 & 2.00 & 8.9 \\
\hline & $\begin{array}{l}\text { Insulate Perimeter of Slab on Grade Foundation with R-12.4 } \\
\text { Insulation }\end{array}$ & 201 & 2,502 & 25,937 & 18,072 & 1.70 & 10.4 \\
\hline & $\begin{array}{l}\text { Replace 300-watt Incandescent Lamps with Fluorescent Fixtures } \\
\text { Including 2x4 3-bulb 32-watt T-8 Lamps and Electronic Ballasts }\end{array}$ & 24 & 1,113 & 3,216 & 16,317 & 6.10 & 2.9 \\
\hline & $\begin{array}{l}\text { Replace 40-watt T-12 Lamps and Magnetic Ballasts with 32-watt } \\
\text { T-8 Lamps and Electronic Ballasts with Reflectors }\end{array}$ & 947 & 28,979 & 176,896 & 332,074 & 2.90 & 6.1 \\
\hline & Replace 75-watt Incandescent Flood Lamps with 23-watt CFLs & 59 & 4,684 & 936 & 80,904 & 87.50 & 0.2 \\
\hline & Subtotal & 1,745 & 43,922 & 266,083 & 505,105 & 2.92 & 6.1 \\
\hline
\end{tabular}




\begin{tabular}{|c|c|c|c|c|c|c|c|}
\hline FEDS Category & Technology Change & \begin{tabular}{|c|} 
Energy \\
Savings \\
$($ MMBtu/yr)
\end{tabular} & $\begin{array}{c}\text { Annual } \\
\text { Savings } \\
(\$ / y r)\end{array}$ & $\begin{array}{c}\text { Capital Cost } \\
(\$)\end{array}$ & $\begin{array}{l}\text { Net Present } \\
\text { Value } \\
\text { (\$) }\end{array}$ & SIR & $\begin{array}{c}\text { Simple } \\
\text { Payback (yr) }\end{array}$ \\
\hline \multirow[t]{6}{*}{ 10ms } & Increase Insulation in Suspended Ceiling by R-19 from R- 5 to R-24 & 1,077 & 8,120 & 78,287 & 64,510 & 1.80 & 9.6 \\
\hline & $\begin{array}{l}\text { Insulate Perimeter of Slab on Grade Foundation with R-12.4 } \\
\text { Insulation }\end{array}$ & 279 & 2,067 & 22,774 & 13,570 & 1.60 & 11.0 \\
\hline & $\begin{array}{l}\text { Replace 2-watt LED Exit Signs with 0.2-watt Electroluminescent } \\
\text { Exit Signs }\end{array}$ & 10 & 628 & 4,311 & 6,633 & 2.50 & 6.9 \\
\hline & $\begin{array}{l}\text { Replace 40-watt T-12 Lamps and Magnetic Ballasts with 28-watt } \\
\text { T-5 Lamps and Electronic Ballasts with Reflectors }\end{array}$ & 1,692 & 39,060 & 273,757 & 412,562 & 2.50 & 7.0 \\
\hline & $\begin{array}{l}\text { Wrap Electric Hot Water Tank with R-11 Fiberglass Batt Insulation; } \\
\text { Insulate Pipes Near Tank; Install Low-Flow Showerheads to Reduce } \\
\text { Water Flow from } 4.8 \text { GPM to } 2.0 \text { GPM; Lower Tank Temperature } \\
\text { from 140F to } 120 \mathrm{~F}\end{array}$ & 9 & 303 & 302 & 1,510 & 14.70 & 1.0 \\
\hline & Subtotal & 3,067 & 50,178 & 379,431 & 498,785 & 2.30 & 7.6 \\
\hline \multirow[t]{6}{*}{$10 \mathrm{hs}$} & Increase Insulation in Suspended Ceiling by R-19 from R-5 to R-24 & 454 & 3,042 & 42,823 & 10,668 & 1.20 & 14.1 \\
\hline & $\begin{array}{l}\text { Insulate Perimeter of Slab on Grade Foundation with R-12.4 } \\
\text { Insulation }\end{array}$ & 86 & 571 & 8,859 & 1,176 & 1.10 & 15.5 \\
\hline & $\begin{array}{l}\text { Replace 2-watt LED Exit Signs with 0.2-watt Electroluminescent } \\
\text { Exit Signs }\end{array}$ & 9 & 615 & 4,311 & 6,422 & 2.50 & 7.0 \\
\hline & \begin{tabular}{|l|} 
Replace 40-watt T-12 Lamps and Magnetic Ballasts with 28-watt \\
T-5 Lamps and Electronic Ballasts with Reflectors \\
\end{tabular} & 1,237 & 30,500 & 224,145 & 311,751 & 2.40 & 7.3 \\
\hline & $\begin{array}{l}\text { Replace Existing Electric Hot Water Heater with Central Heat Pump } \\
\text { Hot Water System (COP=3.32); Wrap Tank with R-11 Fiberglass } \\
\text { Batt Insulation; Install Low-Flow Showerheads to Reduce Water } \\
\text { Flow from 4.8 GPM to 2.0 GPM } \\
\end{array}$ & 197 & 6,196 & 14,299 & 88,091 & 5.20 & 2.3 \\
\hline & Subtotal & 1,983 & 40,924 & 294,437 & 418,108 & 2.34 & 7.2 \\
\hline \multirow[t]{5}{*}{21} & $\begin{array}{l}\text { Increase Attic Insulation by R-19 from R-7 to R-26 with Blow-In } \\
\text { Insulation }\end{array}$ & 90 & 3,288 & 12,537 & 45,287 & 4.60 & 3.8 \\
\hline & $\begin{array}{l}\text { Insulate Perimeter of Slab on Grade Foundation with R-12.4 } \\
\text { Insulation }\end{array}$ & 23 & 736 & 9,996 & 2,952 & 1.30 & 13.6 \\
\hline & $\begin{array}{l}\text { Replace 2-watt LED Exit Signs with 0.2-watt Electroluminescent } \\
\text { Exit Signs }\end{array}$ & 2 & 210 & 1,486 & 2,183 & 2.50 & 7.1 \\
\hline & Replace 60-watt Incandescent Flood Lamps with 18-watt CFLs & 18 & 2,138 & 333 & 36,976 & 112.20 & 0.2 \\
\hline & $\begin{array}{l}\text { Replace Existing Air-Cooled Electric Chiller (COP=2.49) with High } \\
\text { Efficiency Water-Cooled Reciprocating Electric Chiller }(\mathrm{COP}=4.0) \\
\text { and Cooling Tower }\end{array}$ & 198 & 7,021 & 97,291 & 1,229 & 1.01 & 13.9 \\
\hline
\end{tabular}




\begin{tabular}{|c|c|c|c|c|c|c|c|}
\hline FEDS Category & Technology Change & $\begin{array}{c}\text { Energy } \\
\text { Savings } \\
(\mathrm{MMBtu} / \mathrm{yr})\end{array}$ & $\begin{array}{l}\text { Annual } \\
\text { Savings } \\
(\$ / y r)\end{array}$ & $\begin{array}{c}\text { Capital Cost } \\
(\$)\end{array}$ & $\begin{array}{l}\text { Net Present } \\
\text { Value } \\
(\$)\end{array}$ & SIR & $\begin{array}{c}\text { Simple } \\
\text { Payback (yr) }\end{array}$ \\
\hline $21($ contd $)$ & $\begin{array}{l}\text { Replace Existing Electric Hot Water Heater with Central Heat Pump } \\
\text { Hot Water System (COP=2.72); Wrap Tank with R-11 Fiberglass } \\
\text { Batt Insulation; Install Low-Flow Showerheads to Reduce Water } \\
\text { Flow from 4.8 GPM to 2.0 GPM }\end{array}$ & 578 & 18,664 & 61,349 & 238,630 & 3.70 & 3.3 \\
\hline & Subtotal & 909 & 32,057 & 182,992 & 327,257 & 2.56 & 5.7 \\
\hline \multirow[t]{5}{*}{$30 b-1$} & $\begin{array}{l}\text { Insulate Perimeter of Slab on Grade Foundation with R-12.4 } \\
\text { Insulation }\end{array}$ & 20 & 652 & 10,824 & 650 & 1.10 & 16.6 \\
\hline & $\begin{array}{l}\text { Replace 2-watt LED Exit Signs with 0.2-watt Electroluminescent } \\
\text { Exit Signs }\end{array}$ & 9 & 1,038 & 7,136 & 10,985 & 2.50 & 6.9 \\
\hline & $\begin{array}{l}\text { Replace Existing Air-Cooled Electric Chiller }(\mathrm{COP}=2.53) \text { with Very } \\
\text { High Efficiency Water-Cooled Reciprocating Electric Chiller } \\
(\mathrm{COP}=4.2) \text { and Cooling Tower }\end{array}$ & 557 & 18,875 & 201,673 & 43,036 & 1.40 & 10.7 \\
\hline & $\begin{array}{l}\text { Wrap Electric Hot Water Tank with R-11 Fiberglass Batt Insulation; } \\
\text { Insulate Pipes Near Tank; Install Low-Flow Showerheads to Reduce } \\
\text { Water Flow from 4.8 GPM to 2.0 GPM; Install Faucet Aerators }\end{array}$ & 15 & 410 & 860 & 1,880 & 7.00 & 2.1 \\
\hline & Subtotal & 601 & 20,975 & 220,493 & 56,551 & 1.46 & 10.5 \\
\hline \multirow[t]{5}{*}{$30 b-2$} & $\begin{array}{l}\text { Increase Attic Insulation by R-30 from R-7 to R-37 with Blow-In } \\
\text { Insulation }\end{array}$ & 125 & 4,918 & 22,997 & 63,478 & 3.80 & 4.7 \\
\hline & $\begin{array}{l}\text { Insulate Perimeter of Slab on Grade Foundation with R-12.4 } \\
\text { Insulation }\end{array}$ & 26 & 900 & 10,745 & 5,098 & 1.50 & 11.9 \\
\hline & Replace 60-watt Incandescent Lamps with 15-watt CFLs & 544 & 18,867 & 13,489 & 317,733 & 24.60 & 0.7 \\
\hline & $\begin{array}{l}\text { Wrap Propane-Fired Hot Water Tank with R-11 Fiberglass Batt } \\
\text { Insulation; Install Low-Flow Showerheads to Reduce Water Flow } \\
\text { from 4.8 GPM to 2.0 GPM }\end{array}$ & 154 & 2,786 & 250 & 55,636 & 191.00 & 0.1 \\
\hline & Subtotal & 849 & 27,471 & 47,481 & 441,945 & 10.48 & 1.7 \\
\hline \multirow[t]{4}{*}{30 sf-1 } & $\begin{array}{l}\text { Replace 25-watt Incandescent Lamps with 5-watt CFLs and Ballast } \\
\text { Unit }\end{array}$ & 21 & 755 & 10,649 & 2,617 & 1.20 & 14.1 \\
\hline & Replace 75-watt Incandescent Flood Lamps with 23-watt CFLs & 48 & 3,972 & 696 & 68,714 & 99.70 & 0.2 \\
\hline & $\begin{array}{l}\text { Replace Existing } 100 \% \text { Efficient Electric Hot Water Heater with } \\
320 \% \text { Efficient Residential Add-On Heat Pump Water Heater; } \\
\text { Install Low-Flow Showerheads to Reduce Water Flow from } \\
4.8 \text { GPM to } 2.0 \text { GPM }\end{array}$ & 296 & 8,462 & 22,608 & 32,875 & 3.70 & 2.7 \\
\hline & Subtotal & 365 & 13,189 & 33,953 & 104,206 & 5.01 & 2.6 \\
\hline \multirow[t]{2}{*}{30 sf-4 } & $\begin{array}{l}\text { Insulate Perimeter of Slab on Grade Foundation with R-12.4 } \\
\text { Insulation }\end{array}$ & 58 & 1,943 & 27,293 & 6,878 & 1.30 & 14.0 \\
\hline & $\begin{array}{l}\text { Replace 3x40-watt Incandescent Lamps with 2x9-watt CFLs and } \\
\text { ballast unit }\end{array}$ & 543 & 17,680 & 52,989 & 257,436 & 5.90 & 3.0 \\
\hline
\end{tabular}




\begin{tabular}{|c|c|c|c|c|c|c|c|}
\hline FEDS Category & Technology Change & $\begin{array}{c}\begin{array}{c}\text { Energy } \\
\text { Savings } \\
(\mathrm{MMBtu} / \mathrm{yr})\end{array} \\
\end{array}$ & $\begin{array}{l}\text { Annual } \\
\text { Savings } \\
(\$ / y r)\end{array}$ & $\begin{array}{c}\text { Capital Cost } \\
(\$) \\
\end{array}$ & $\begin{array}{l}\text { Net Present } \\
\text { Value } \\
(\$)\end{array}$ & SIR & \begin{tabular}{|c} 
Simple \\
Payback (yr)
\end{tabular} \\
\hline \multirow[t]{3}{*}{30 sf-4 (contd) } & Replace 60-watt Incandescent Flood Lamps with 18 -watt CFLs & 54 & 6,674 & 960 & 115,529 & 121.40 & 0.1 \\
\hline & $\begin{array}{l}\text { Wrap Electric Hot Water Tank with R-11 Fiberglass Batt Insulation; } \\
\text { Insulate Pipes Near Tank; Install Low-Flow Showerheads to Reduce } \\
\text { Water Flow from 4.8 GPM to 2.0 GPM; Install Faucet Aerators }\end{array}$ & 140 & 4,229 & 4,623 & 20,917 & 13.40 & 1.1 \\
\hline & Subtotal & 795 & 30,526 & 85,865 & 400,760 & 6.13 & 2.8 \\
\hline \multirow[t]{4}{*}{$40 \mathrm{a} 2$} & $\begin{array}{l}\text { Replace 40-watt T-12 Lamps and Magnetic Ballasts with 32-watt } \\
\text { T-8 Lamps and Electronic Ballasts }\end{array}$ & 12 & 631 & 7,917 & 3,130 & 1.38 & 12.5 \\
\hline & $\begin{array}{l}\text { Replace Existing } 100 \% \text { Efficient Electric Hot Water Heater with } \\
370 \% \text { Efficient Commercial Heat Pump Water Heater; Install Faucet } \\
\text { Aerators }\end{array}$ & 0 & 21 & 44 & 85 & 4.50 & 2.1 \\
\hline & $\begin{array}{l}\text { Wrap Electric Hot Water Tank with R-11 Fiberglass Batt Insulation; } \\
\text { Insulate Pipes Near Tank; Install Faucet Aerators }\end{array}$ & 0 & 1 & 8 & 1 & 1.40 & 8.0 \\
\hline & Subtotal & 12 & 653 & 7,969 & 3,216 & 1.39 & 12.2 \\
\hline \multirow[t]{2}{*}{$40 \mathrm{~b}$} & $\begin{array}{l}\text { Replace 40-watt T-12 Lamps and Magnetic Ballasts with 32-watt } \\
\text { T-8 Lamps and Electronic Ballasts }\end{array}$ & 47 & 2,217 & 16,859 & 22,040 & 2.30 & 7.6 \\
\hline & Subtotal & 47 & 2,217 & 16,859 & 22,040 & 2.30 & 7.6 \\
\hline \multirow[t]{2}{*}{$40 \mathrm{c} 1$} & $\begin{array}{l}\text { Replace 2-watt LED Exit Signs with 0.35-watt Electroluminescent } \\
\text { Exit Signs }\end{array}$ & 0 & 33 & 252 & 304 & 2.20 & 7.6 \\
\hline & Subtotal & 0 & 33 & 252 & 304 & 2.20 & 7.6 \\
\hline \multirow[t]{3}{*}{$40 \mathrm{c} 2$} & $\begin{array}{l}\text { Insulate Perimeter of Slab on Grade Foundation with R-12.4 } \\
\text { Insulation }\end{array}$ & 2 & 69 & 888 & 327 & 1.40 & 12.9 \\
\hline & $\begin{array}{l}\text { Replace 2-watt LED Exit Signs with 0.35-watt Electroluminescent } \\
\text { Exit Signs }\end{array}$ & 0 & 35 & 252 & 354 & 2.40 & 7.2 \\
\hline & Subtotal & 2 & 104 & 1,140 & 681 & 1.64 & 11.0 \\
\hline \multirow[t]{5}{*}{$50-2$} & Increase Insulation in Suspended Ceiling by R-19 from R-7 to R-26 & 7 & 244 & 3,762 & 542 & 1.10 & 15.4 \\
\hline & $\begin{array}{l}\text { Insulate Perimeter of Slab on Grade Foundation with R-12.4 } \\
\text { Insulation }\end{array}$ & 2 & 82 & 1,393 & 40 & 1.03 & 17.0 \\
\hline & $\begin{array}{l}\text { Replace 40-watt T-12 Lamps and Magnetic Ballasts with 28-watt } \\
\text { T-5 Lamps and Electronic Ballasts with Reflectors }\end{array}$ & 22 & 827 & 5,336 & 9,197 & 2.70 & 6.5 \\
\hline & $\begin{array}{l}\text { Replace Existing Electric Package AC Unit }(\mathrm{COP}=2.41) \text { with Small } \\
\text { Single-Zone Packaged AC Unit (COP=3.57) }\end{array}$ & 28 & 996 & 10,012 & 281 & 1.20 & 10.1 \\
\hline & Subtotal & 59 & 2,149 & 20,503 & 10,060 & 1.74 & 9.5 \\
\hline
\end{tabular}




\begin{tabular}{|c|c|c|c|c|c|c|c|}
\hline FEDS Category & Technology Change & $\begin{array}{c}\text { Energy } \\
\text { Savings } \\
(\mathrm{MMBtu} / \mathrm{yr})\end{array}$ & $\begin{array}{c}\text { Annual } \\
\text { Savings } \\
(\$ / y r)\end{array}$ & $\begin{array}{c}\text { Capital Cost } \\
(\$)\end{array}$ & $\begin{array}{l}\text { Net Present } \\
\text { Value } \\
(\$)\end{array}$ & SIR & $\begin{array}{c}\text { Simple } \\
\text { Payback (yr) }\end{array}$ \\
\hline \multirow[t]{4}{*}{$60 \mathrm{a} 1$} & $\begin{array}{l}\text { Replace 2-watt LED Exit Signs with 0.2-watt Electroluminescent } \\
\text { Exit Signs }\end{array}$ & 1 & 137 & 1,015 & 1,366 & 2.30 & 7.4 \\
\hline & $\begin{array}{l}\text { Replace Existing 100\% Efficient Electric Hot Water Heater with } \\
370 \% \text { Efficient Commercial Heat Pump Water Heater }\end{array}$ & 66 & 2,357 & 2,802 & 15,892 & 8.30 & 1.2 \\
\hline & $\begin{array}{l}\text { Replace Existing Electric Package AC Unit }(\mathrm{COP}=2.57) \text { with Water- } \\
\text { Cooled Centrifugal Electric Chiller, with Ultra High Efficiency Fan } \\
\text { Coils Replacing Window Units, and Cooling Tower (overall } \\
\text { COP=6.33) }\end{array}$ & 2,195 & 66,250 & 694,817 & 186,245 & 1.40 & 10.5 \\
\hline & Subtotal & 2,262 & 68,744 & 698,634 & 203,503 & 1.43 & 10.2 \\
\hline \multirow[t]{7}{*}{$60 \mathrm{a} 2$} & Increase Insulation in Suspended Ceiling by R-19 from R-7 to R-26 & 401 & 14,518 & 126,619 & 128,684 & 2.00 & 8.7 \\
\hline & $\begin{array}{l}\text { Insulate Perimeter of Slab on Grade Foundation with R-12.4 } \\
\text { Insulation }\end{array}$ & 23 & 774 & 7,071 & 6,544 & 1.90 & 9.1 \\
\hline & $\begin{array}{l}\text { Replace 2-watt LED Exit Signs with 0.2-watt Electroluminescent } \\
\text { Exit Signs }\end{array}$ & 1 & 99 & 723 & 1,021 & 2.40 & 7.3 \\
\hline & $\begin{array}{l}\text { Replace 2-watt LED Exit Signs with 0.35-watt Electroluminescent } \\
\text { Exit Signs }\end{array}$ & 0 & 8 & 60 & 87 & 2.40 & 7.5 \\
\hline & $\begin{array}{l}\text { Replace Existing 100\% Efficient Electric Hot Water Heater with } \\
370 \% \text { Efficient Commercial Heat Pump Water Heater }\end{array}$ & 26 & 883 & 1,593 & 5,527 & 5.40 & 1.8 \\
\hline & $\begin{array}{l}\text { Replace Existing 76\% Efficient Propane-Fired Hot Water Heater } \\
\text { with } 370 \% \text { Efficient Commercial Heat Pump Water Heater }\end{array}$ & 36 & 583 & 1,593 & 2,790 & 3.80 & 2.7 \\
\hline & Subtotal & 487 & 16,865 & 137,659 & 144,653 & 2.04 & 8.2 \\
\hline \multirow[t]{6}{*}{$60 b$} & $\begin{array}{l}\text { Insulate Perimeter of Slab on Grade Foundation with R-12.4 } \\
\text { Insulation }\end{array}$ & 50 & 1,620 & 18,803 & 9,684 & 1.50 & 11.6 \\
\hline & $\begin{array}{l}\text { Replace 96-watt T12 Fluorescent Lamps and Magnetic Ballasts with } \\
\text { Energy-Saving 96-watt T12 Lamps and Electronic Ballasts with } \\
\text { Reflectors }\end{array}$ & 333 & 12,328 & 56,254 & 160,262 & 3.80 & 4.6 \\
\hline & $\begin{array}{l}\text { Replace Existing Air-Cooled Electric Chiller }(\mathrm{COP}=2.53) \text { with Very } \\
\text { High Efficiency Water-Cooled Reciprocating Electric Chiller } \\
(\mathrm{COP}=4.2) \text { and Cooling Tower }\end{array}$ & 632 & 21,102 & 144,388 & 94,713 & 2.10 & 6.8 \\
\hline & $\begin{array}{l}\text { Replace Existing Electric Package AC Unit }(\mathrm{COP}=2.66) \text { with Ultra } \\
\text { High Efficiency Window Unit (COP=3.37) }\end{array}$ & 50 & 1,692 & 18,320 & 815 & 1.10 & 10.8 \\
\hline & $\begin{array}{l}\text { Wrap Electric Hot Water Tank with R-11 Fiberglass Batt Insulation; } \\
\text { Insulate Pipes Near Tank; Install Low-Flow Showerheads to Reduce } \\
\text { Water Flow from } 4.8 \text { GPM to } 2.0 \mathrm{GPM} \text {; Install Faucet Aerators; } \\
\text { Lower Tank Temperature from } 140 \mathrm{~F} \text { to } 120 \mathrm{~F}\end{array}$ & 2 & 56 & 96 & 266 & 8.60 & 1.7 \\
\hline & Subtotal & 1,067 & 36,798 & 237,861 & 265,740 & 2.56 & 6.5 \\
\hline
\end{tabular}




\begin{tabular}{|c|c|c|c|c|c|c|c|}
\hline FEDS Category & Technology Change & $\begin{array}{c}\text { Energy } \\
\text { Savings } \\
(\text { MMBtu/yr) }\end{array}$ & $\begin{array}{l}\text { Annual } \\
\text { Savings } \\
(\$ / y r)\end{array}$ & $\begin{array}{l}\text { Capital Cost } \\
(\$)\end{array}$ & $\begin{array}{l}\text { Net Present } \\
\text { Value } \\
\text { (\$) }\end{array}$ & SIR & $\begin{array}{c}\text { Simple } \\
\text { Payback (yr) }\end{array}$ \\
\hline \multirow[t]{8}{*}{$60 \mathrm{c}$} & $\begin{array}{l}\text { Insulate Perimeter of Slab on Grade Foundation with R-12.4 } \\
\text { Insulation }\end{array}$ & 129 & 1,689 & 19,282 & 10,424 & 1.50 & 11.4 \\
\hline & Insulate Pipes Near Electric Hot Water Tank & 16 & 480 & 2,302 & 264 & 1.10 & 4.8 \\
\hline & $\begin{array}{l}\text { Replace 25-watt Incandescent Lamps with 5-watt CFLs and ballast } \\
\text { unit }\end{array}$ & 757 & 18,956 & 158,158 & 174,948 & 2.10 & 8.3 \\
\hline & $\begin{array}{l}\text { Replace 2-watt LED Exit Signs with 0.2-watt Electroluminescent } \\
\text { Exit Signs }\end{array}$ & 6 & 486 & 3,369 & 5,136 & 2.50 & 6.9 \\
\hline & $\begin{array}{l}\text { Replace 40-watt T-12 Lamps and Magnetic Ballasts with 32-watt } \\
\text { T-8 Lamps and Electronic Ballasts with Reflectors }\end{array}$ & 337 & 9,340 & 46,796 & 117,281 & 3.50 & 5.0 \\
\hline & $\begin{array}{l}\text { Replace Existing 69\% Efficient Propane-Fired Hot Water Heater } \\
\text { with 91\% Efficient Condensing Model; Wrap Hot Water Tank with } \\
\text { R-11 Fiberglass Batt Insulation }\end{array}$ & 703 & 12,062 & 52,998 & 144,661 & 4.50 & 4.4 \\
\hline & $\begin{array}{l}\text { Replace Existing Air-Cooled Electric Chiller }(\mathrm{COP}=2.53) \text { with Very } \\
\text { High Efficiency Water-Cooled Reciprocating Electric Chiller } \\
(\mathrm{COP}=4.2) \text { and Cooling Tower }\end{array}$ & 950 & 31,124 & 189,008 & 152,892 & 2.40 & 6.1 \\
\hline & Subtotal & 2,898 & 74,137 & 471,913 & 605,606 & 2.58 & 6.4 \\
\hline \multirow[t]{6}{*}{80} & $\begin{array}{l}\text { Insulate Perimeter of Slab on Grade Foundation with R-12.4 } \\
\text { Insulation }\end{array}$ & 91 & 3,085 & 33,444 & 20,810 & 1.60 & 10.8 \\
\hline & $\begin{array}{l}\text { Replace 2-watt LED Exit Signs with 0.2-watt Electroluminescent } \\
\text { Exit Signs }\end{array}$ & 13 & 1,426 & 9,491 & 15,414 & 2.60 & 6.7 \\
\hline & $\begin{array}{l}\text { Replace 40-watt T-12 Lamps and Magnetic Ballasts with 32-watt } \\
\text { T-8 Lamps and Electronic Ballasts with Reflectors }\end{array}$ & 78 & 2,773 & 11,167 & 37,566 & 4.40 & 4.0 \\
\hline & $\begin{array}{l}\text { Wrap Electric Hot Water Tank with R-11 Fiberglass Batt Insulation; } \\
\text { Insulate Pipes Near Tank; Install Low-Flow Showerheads to Reduce } \\
\text { Water Flow from } 4.8 \mathrm{GPM} \text { to } 2.0 \mathrm{GPM} \text {; Lower Tank Temperature } \\
\text { from } 125 \mathrm{~F} \text { to } 120 \mathrm{~F}\end{array}$ & 1 & 42 & 330 & 107 & 1.90 & 7.9 \\
\hline & $\begin{array}{l}\text { Wrap Propane-Fired Hot Water Tank with R-11 Fiberglass Batt } \\
\text { Insulation; Install Low-Flow Showerheads to Reduce Water Flow } \\
\text { from 4.8 GPM to 2.0 GPM }\end{array}$ & 194 & 3,522 & 336 & 70,310 & 179.80 & 0.1 \\
\hline & Subtotal & 377 & 10,848 & 54,768 & 144,207 & 3.58 & 5.0 \\
\hline \multicolumn{2}{|l|}{ Grand Total } & 28,204 & 851,122 & $5,166,277$ & $8,718,604$ & 2.91 & 6.1 \\
\hline
\end{tabular}





\section{Appendix C-2 \\ Comprehensive List of Cost-Effective Projects Identified from the FEDS Assessment Using Alternative Financing Source of Capital}

The following table identifies the 91 cost-effective energy- and cost-reducing retrofit projects identified from the FEDS modeling and analysis based on the assumption that they will be funded using alternative financing source of capital funds. Alternative financing includes UESC and ESPC, as well as any other third party financing. Key energy and economic results are presented for each cost-effective retrofit measure. The projects are grouped by building category. More detail, supporting each line-item project recommendation, is contained in the FEDS input and output files, which are delivered to the site energy manager on a CD in conjunction with this report. 


\begin{tabular}{|c|c|c|c|c|c|c|c|}
\hline FEDS Category & Technology Change & \begin{tabular}{c|} 
Energy \\
Savings \\
(MMBtu/yr)
\end{tabular} & $\begin{array}{l}\text { Annual } \\
\text { Savings } \\
(\$ / y r)\end{array}$ & $\begin{array}{c}\text { Capital Cost } \\
(\$)\end{array}$ & $\begin{array}{l}\text { Net Present } \\
\text { Value } \\
(\$)\end{array}$ & SIR & $\begin{array}{c}\text { Simple } \\
\text { Payback (yr) }\end{array}$ \\
\hline \multirow[t]{2}{*}{1} & $\begin{array}{l}\text { Replace 40-watt T-12 Lamps and Magnetic Ballasts with 32-watt } \\
\text {-8 -8 Lamps and Electronic Ballasts }\end{array}$ & 120 & 5,199 & 37,327 & 14,963 & 1.43 & 7.2 \\
\hline & Subtotal & 120 & 5,199 & 37,327 & 14,963 & 1.43 & 7.2 \\
\hline \multirow[t]{3}{*}{ 10a } & $\begin{array}{l}\text { Increase Attic Insulation by R-13 from R-5 to R-18 with Blow-In } \\
\text { Insulation }\end{array}$ & 187 & 7,164 & 22,308 & 49,543 & 3.20 & 3.1 \\
\hline & $\begin{array}{l}\text { Replace 2-watt LED Exit Signs with 0.2-watt Electroluminescent } \\
\text { Exit Signs }\end{array}$ & 4 & 440 & 3,442 & 980 & 1.30 & 7.8 \\
\hline & Subtotal & 191 & 7,604 & 25,750 & 50,523 & 2.96 & 3.4 \\
\hline \multirow[t]{7}{*}{ 10b1 } & $\begin{array}{l}\text { Increase Attic Insulation by R-13 from R-5 to R-18 with Blow-In } \\
\text { Insulation }\end{array}$ & 74 & 2,336 & 16,041 & 7,388 & 1.50 & 6.9 \\
\hline & $\begin{array}{l}\text { Replace 2-watt LED Exit Signs with 0.35-watt Electroluminescent } \\
\text { Exit Signs }\end{array}$ & 0 & 60 & 503 & 103 & 1.20 & 8.4 \\
\hline & $\begin{array}{l}\text { Replace 40-watt T-12 Lamps and Magnetic Ballasts with 32-watt } \\
\text { T-8 Lamps and Electronic Ballasts }\end{array}$ & 155 & 7,078 & 36,127 & 35,033 & 2.03 & 5.1 \\
\hline & $\begin{array}{l}\text { Replace Existing Air-Cooled Electric Chiller (COP=2.53) with Very } \\
\text { High Efficiency Water-Cooled Reciprocating Electric Chiller } \\
(\mathrm{COP}=4.2) \text { and Cooling Tower }\end{array}$ & 66 & 2,662 & 22,686 & 4,014 & 1.20 & 8.5 \\
\hline & $\begin{array}{l}\text { Wrap Electric Hot Water Tank with R-11 Fiberglass Batt Insulation; } \\
\text { Insulate Pipes Near Tank; Install Faucet Aerators }\end{array}$ & 1 & 23 & 106 & 130 & 2.20 & 4.6 \\
\hline & $\begin{array}{l}\text { Wrap Electric Hot Water Tank with R-11 Fiberglass Batt Insulation; } \\
\text { Insulate Pipes Near Tank; Install Low-Flow Showerheads to Reduce } \\
\text { Water Flow from 4.8 GPM to 2.0 GPM; Install Faucet Aerators }\end{array}$ & 2 & 81 & 162 & 657 & 5.00 & 2.0 \\
\hline & Subtotal & 298 & 12,240 & 75,625 & 47,325 & 1.68 & 6.2 \\
\hline \multirow[t]{5}{*}{ 10b2 } & $\begin{array}{l}\text { Replace 100-watt Metal Halide Lamps with 100-watt High Pressure } \\
\text { Sodium Lamps }\end{array}$ & 1 & 204 & 1,829 & 227 & 1.10 & 9.0 \\
\hline & $\begin{array}{l}\text { Replace 2-watt LED Exit Signs with 0.35-watt Electroluminescent } \\
\text { Exit Signs }\end{array}$ & 0 & 31 & 252 & 57 & 1.20 & 8.1 \\
\hline & $\begin{array}{l}\text { Replace 40-watt T-12 Lamps and Magnetic Ballasts with 32-watt } \\
\text { T-8 Lamps and Electronic Ballasts }\end{array}$ & 22 & 964 & 3,306 & 6,370 & 2.90 & 3.4 \\
\hline & $\begin{array}{l}\text { Wrap Electric Hot Water Tank with R-11 Fiberglass Batt Insulation; } \\
\text { Insulate Pipes Near Tank; Install Faucet Aerators }\end{array}$ & 2 & 58 & 162 & 429 & 3.67 & 2.8 \\
\hline & Subtotal & 25 & 1,257 & 5,549 & 7,083 & 2.17 & 4.4 \\
\hline
\end{tabular}




\begin{tabular}{|c|c|c|c|c|c|c|c|}
\hline FEDS Category & Technology Change & \begin{tabular}{|c|} 
Energy \\
Savings \\
$(\mathbf{M M B t u} / \mathbf{y r})$
\end{tabular} & $\begin{array}{l}\text { Annual } \\
\text { Savings } \\
(\$ / y r)\end{array}$ & $\begin{array}{c}\text { Capital Cost } \\
(\$)\end{array}$ & $\begin{array}{l}\text { Net Present } \\
\text { Value } \\
\text { (\$) }\end{array}$ & SIR & $\begin{array}{c}\text { Simple } \\
\text { Payback (yr) }\end{array}$ \\
\hline \multirow[t]{3}{*}{$10 \mathrm{~d}$} & $\begin{array}{l}\text { Increase Attic Insulation by R-19 from R-5 to R-24 with Blow-In } \\
\text { Insulation }\end{array}$ & 676 & 25,752 & 50,244 & 208,045 & 5.10 & 2.0 \\
\hline & $\begin{array}{l}\text { Replace 2-watt LED Exit Signs with 0.2-watt Electroluminescent } \\
\text { Exit Signs }\end{array}$ & 8 & 785 & 5,724 & 2,196 & 1.40 & 7.3 \\
\hline & Subtotal & 684 & 26,537 & 55,968 & 210,241 & 4.74 & 2.1 \\
\hline \multirow[t]{4}{*}{$10 \mathrm{e}$} & $\begin{array}{l}\text { Increase Attic Insulation by R-19 from R-5 to R-24 with Blow-In } \\
\text { Insulation }\end{array}$ & 534 & 20,138 & 52,908 & 149,077 & 3.80 & 2.6 \\
\hline & $\begin{array}{l}\text { Replace 2-watt LED Exit Signs with 0.2-watt Electroluminescent } \\
\text { Exit Signs }\end{array}$ & 4 & 384 & 2,898 & 975 & 1.30 & 7.5 \\
\hline & $\begin{array}{l}\text { Replace Existing Air-Cooled Electric Chiller }(\mathrm{COP}=2.53) \text { with Very } \\
\text { High Efficiency Water-Cooled Reciprocating Electric Chiller } \\
(\mathrm{COP}=4.2) \text { and Cooling Tower }\end{array}$ & 310 & 11,032 & 81,404 & 13,388 & 1.20 & 7.4 \\
\hline & Subtotal & 848 & 31,554 & 137,210 & 163,440 & 2.32 & 4.3 \\
\hline \multirow[t]{3}{*}{$10 \mathrm{f}$} & $\begin{array}{l}\text { Increase Attic Insulation by R-19 from R-5 to R-24 with Blow-In } \\
\text { Insulation }\end{array}$ & 432 & 16,988 & 37,461 & 132,935 & 4.50 & 2.2 \\
\hline & $\begin{array}{l}\text { Replace 2-watt LED Exit Signs with 0.2-watt Electroluminescent } \\
\text { Exit Signs }\end{array}$ & 9 & 906 & 6,665 & 2,481 & 1.40 & 7.4 \\
\hline & Subtotal & 441 & 17,894 & 44,126 & 135,416 & 4.06 & 2.5 \\
\hline \multirow[t]{4}{*}{$10 \mathrm{~g}$} & Increase Insulation in Suspended Ceiling by R-11 from R-7 to R-18 & 90 & 3,233 & 30,491 & 1,931 & 1.10 & 9.4 \\
\hline & $\begin{array}{l}\text { Replace 2-watt LED Exit Signs with 0.2-watt Electroluminescent } \\
\text { Exit Signs }\end{array}$ & 6 & 587 & 4,311 & 1,607 & 1.40 & 7.3 \\
\hline & Replace 60-watt Incandescent Flood Lamps with 18-watt CFLs & 15 & 1,751 & 272 & 17,419 & 65.00 & 0.2 \\
\hline & Subtotal & 111 & 5,571 & 35,074 & 20,957 & 1.89 & 6.3 \\
\hline \multirow[t]{7}{*}{$10 \operatorname{tr}$} & $\begin{array}{l}\text { Add Blow-in Wall Insulation to Fill Available Space, from R-0 to } \\
\text { R-22.2 }\end{array}$ & 3,548 & 113,474 & 397,268 & 740,879 & 2.90 & 3.5 \\
\hline & $\begin{array}{l}\text { Increase Attic Insulation by R-19 from R-5 to R-24 with Blow-In } \\
\text { Insulation }\end{array}$ & 478 & 15,330 & 25,245 & 128,520 & 6.10 & 1.6 \\
\hline & $\begin{array}{l}\text { Replace 40-watt T-12 Lamps and Magnetic Ballasts with 32-watt } \\
\text { T-8 Lamps and Electronic Ballasts }\end{array}$ & 512 & 23,193 & 87,756 & 145,310 & 2.70 & 3.8 \\
\hline & Replace 75-watt Incandescent Flood Lamps with 23-watt CFLs & 42 & 3,311 & 653 & 32,742 & 51.20 & 0.2 \\
\hline & $\begin{array}{l}\text { Replace Existing Electric Package AC Unit }(\mathrm{COP}=2.52) \text { with Small } \\
\text { Single-Zone Packaged AC Unit (COP=3.57) }\end{array}$ & 159 & 9,785 & 70,312 & 153,656 & 3.20 & 7.2 \\
\hline & $\begin{array}{l}\text { Replace Existing Metal Frame, Single Pane Windows with } \\
\text { Aluminum Frame, Double Pane, Argon-Filled Windows with Super } \\
\text { Low-e Film }\end{array}$ & 139 & 4,124 & 39,932 & 1,439 & 1.04 & 9.7 \\
\hline & Subtotal & 4,878 & 169,217 & 621,166 & $1,202,546$ & 2.97 & 3.7 \\
\hline
\end{tabular}




\begin{tabular}{|c|c|c|c|c|c|c|c|}
\hline FEDS Category & Technology Change & $\begin{array}{c}\text { Energy } \\
\text { Savings } \\
(\text { MMBtu/yr) }\end{array}$ & $\begin{array}{l}\text { Annual } \\
\text { Savings } \\
(\$ / y r)\end{array}$ & $\begin{array}{c}\text { Capital Cost } \\
(\$)\end{array}$ & $\begin{array}{l}\text { Net Present } \\
\text { Value } \\
\text { (\$) }\end{array}$ & SIR & $\begin{array}{c}\text { Simple } \\
\text { Payback (yr) }\end{array}$ \\
\hline \multirow[t]{6}{*}{10 is } & Increase Insulation in Suspended Ceiling by R-19 from R- 5 to R-24 & 269 & 8,377 & 52,223 & 31,799 & 1.60 & 6.2 \\
\hline & $\begin{array}{l}\text { Insulate Perimeter of Slab on Grade Foundation with R-12.4 } \\
\text { Insulation }\end{array}$ & 98 & 2,911 & 20,412 & 8,788 & 1.40 & 7.0 \\
\hline & $\begin{array}{l}\text { Replace 300-watt Incandescent Lamps with Fluorescent Fixtures } \\
\text { Including 2x4 3-bulb 32-watt T-8 Lamps and Electronic Ballasts }\end{array}$ & 33 & 1,539 & 4,293 & 11,171 & 3.60 & 2.8 \\
\hline & $\begin{array}{l}\text { Replace 40-watt T-12 Lamps and Magnetic Ballasts with 32-watt } \\
\text { T-8 Lamps and Electronic Ballasts }\end{array}$ & 432 & 19,270 & 69,891 & 123,739 & 2.80 & 3.6 \\
\hline & $\begin{array}{l}\text { Replace Existing Metal Louvers and Plastic Windows with } \\
\text { Aluminum Frame, Double Pane, Argon-Filled Windows with Super } \\
\text { Low-e Film }\end{array}$ & 700 & 22,958 & 190,961 & 39,307 & 1.20 & 8.3 \\
\hline & Subtotal & 1,532 & 55,055 & 337,780 & 214,804 & 1.62 & 6.1 \\
\hline \multirow[t]{5}{*}{$10 \mathrm{es}$} & Increase Insulation in Suspended Ceiling by R-11 from R-5 to R-16 & 393 & 5,135 & 43,723 & 7,781 & 1.20 & 8.5 \\
\hline & \begin{tabular}{|l} 
Replace 300-watt Incandescent Lamps with Fluorescent Fixtures \\
Including 2x4 3-bulb 32-watt T-8 Lamps and Electronic Ballasts
\end{tabular} & 24 & 1,152 & 3,216 & 8,368 & 3.60 & 2.8 \\
\hline & $\begin{array}{l}\text { Replace 40-watt T-12 Lamps and Magnetic Ballasts with 32-watt } \\
\text { T-8 Lamps and Electronic Ballasts }\end{array}$ & 748 & 25,756 & 98,548 & 160,285 & 2.60 & 3.8 \\
\hline & Replace 75-watt Incandescent Flood Lamps with 23-watt CFLs & 59 & 4,694 & 936 & 46,424 & 50.60 & 0.2 \\
\hline & Subtotal & 1,224 & 36,737 & 146,423 & 222,858 & 2.56 & 4.0 \\
\hline \multirow[t]{5}{*}{$10 \mathrm{~ms}$} & Increase Insulation in Suspended Ceiling by R-11 from R-5 to R-16 & 825 & 6,247 & 57,919 & 4,739 & 1.10 & 9.3 \\
\hline & $\begin{array}{l}\text { Replace 2-watt LED Exit Signs with 0.2-watt Electroluminescent } \\
\text { Exit Signs }\end{array}$ & 10 & 572 & 4,311 & 1,454 & 1.30 & 7.5 \\
\hline & $\begin{array}{l}\text { Replace 40-watt T-12 Lamps and Magnetic Ballasts with 32-watt } \\
\text { T-8 Lamps and Electronic Ballasts }\end{array}$ & 1,098 & 31,652 & 153,671 & 164,517 & 2.10 & 4.9 \\
\hline & $\begin{array}{l}\text { Wrap Electric Hot Water Tank with R-11 Fiberglass Batt Insulation; } \\
\text { Insulate Pipes Near Tank; Install Low-Flow Showerheads to Reduce } \\
\text { Water Flow from } 4.8 \text { GPM to } 2.0 \text { GPM; Lower Tank Temperature } \\
\text { from } 140 \mathrm{~F} \text { to } 120 \mathrm{~F}\end{array}$ & 9 & 303 & 302 & 2,738 & 10.10 & 1.0 \\
\hline & Subtotal & 1,942 & 38,774 & 216,203 & 173,448 & 1.86 & 5.6 \\
\hline \multirow[t]{2}{*}{ 10hs } & $\begin{array}{l}\text { Replace 2-watt LED Exit Signs with 0.2-watt Electroluminescent } \\
\text { Exit Signs }\end{array}$ & 8 & 559 & 4,311 & 1,324 & 1.30 & 7.7 \\
\hline & $\begin{array}{l}\text { Replace 40-watt T-12 Lamps and Magnetic Ballasts with 32-watt } \\
\text { T-8 Lamps and Electronic Ballasts }\end{array}$ & 796 & 24,914 & 125,822 & 124,657 & 2.00 & 5.1 \\
\hline
\end{tabular}




\begin{tabular}{|c|c|c|c|c|c|c|c|}
\hline FEDS Category & Technology Change & $\begin{array}{c}\text { Energy } \\
\text { Savings } \\
\text { (MMBtu/yr) }\end{array}$ & $\begin{array}{l}\text { Annual } \\
\text { Savings } \\
(\$ / y r)\end{array}$ & $\begin{array}{c}\text { Capital Cost } \\
(\$)\end{array}$ & $\begin{array}{l}\text { Net Present } \\
\text { Value } \\
\text { (\$) }\end{array}$ & SIR & $\begin{array}{c}\text { Simple } \\
\text { Payback (yr) }\end{array}$ \\
\hline \multirow[t]{2}{*}{ 10hs (contd) } & $\begin{array}{l}\text { Replace Existing Electric Hot Water Heater with Central Heat Pump } \\
\text { Hot Water System (COP=3.32); Wrap Tank with R-11 Fiberglass } \\
\text { Batt Insulation; Install Low-Flow Showerheads to Reduce Water } \\
\text { Flow from 4.8 GPM to 2.0 GPM }\end{array}$ & 197 & 6,196 & 14,299 & 47,848 & 4.30 & 2.3 \\
\hline & Subtotal & 1,001 & 31,669 & 144,432 & 173,829 & 2.21 & 4.6 \\
\hline \multirow[t]{5}{*}{21} & $\begin{array}{l}\text { Increase Attic Insulation by R-19 from R-7 to R-26 with Blow-In } \\
\text { Insulation }\end{array}$ & 112 & 4,265 & 12,537 & 30,246 & 3.40 & 2.9 \\
\hline & $\begin{array}{l}\text { Replace 2-watt LED Exit Signs with 0.2-watt Electroluminescent } \\
\text { Exit Signs }\end{array}$ & 2 & 195 & 1,486 & 484 & 1.30 & 7.6 \\
\hline & Replace 60-watt Incandescent Flood Lamps with 18-watt CFLs & 18 & 2,141 & 333 & 21,294 & 65.00 & 0.2 \\
\hline & $\begin{array}{l}\text { Replace Existing Electric Hot Water Heater with Central Heat Pump } \\
\text { Hot Water System (COP=2.72); Wrap Tank with R-11 Fiberglass } \\
\text { Batt Insulation; Install Low-Flow Showerheads to Reduce Water } \\
\text { Flow from 4.8 GPM to 2.0 GPM }\end{array}$ & 578 & 18,664 & 61,349 & 125,907 & 3.10 & 3.3 \\
\hline & Subtotal & 710 & 25,265 & 75,705 & 177,931 & 3.39 & 3.0 \\
\hline \multirow[t]{3}{*}{$30 \mathrm{~b}-1$} & $\begin{array}{l}\text { Replace 2-watt LED Exit Signs with 0.2-watt Electroluminescent } \\
\text { Exit Signs }\end{array}$ & 10 & 977 & 7,136 & 2,724 & 1.40 & 7.3 \\
\hline & $\begin{array}{l}\text { Wrap Electric Hot Water Tank with R-11 Fiberglass Batt Insulation; } \\
\text { Insulate Pipes Near Tank; Install Low-Flow Showerheads to Reduce } \\
\text { Water Flow from 4.8 GPM to 2.0 GPM; Install Faucet Aerators }\end{array}$ & 15 & 410 & 860 & 3,257 & 4.80 & 2.1 \\
\hline & Subtotal & 25 & 1,387 & 7,996 & 5,981 & 1.78 & 5.8 \\
\hline \multirow[t]{4}{*}{$30 \mathrm{~b}-2$} & $\begin{array}{l}\text { Increase Attic Insulation by R-19 from R-7 to R-26 with Blow-In } \\
\text { Insulation }\end{array}$ & 110 & 4,282 & 14,537 & 28,405 & 3.00 & 3.4 \\
\hline & Replace 60-watt Incandescent Lamps with 15-watt CFLs & 543 & 18,891 & 13,489 & 176,281 & 14.10 & 0.7 \\
\hline & $\begin{array}{l}\text { Wrap Propane-Fired Hot Water Tank with R-11 Fiberglass Batt } \\
\text { Insulation; Install Low-Flow Showerheads to Reduce Water Flow } \\
\text { from 4.8 GPM to 2.0 GPM }\end{array}$ & 154 & 2,786 & 250 & 30,543 & 123.10 & 0.1 \\
\hline & Subtotal & 807 & 25,959 & 28,276 & 235,229 & 9.43 & 1.1 \\
\hline \multirow[t]{3}{*}{$30 \mathrm{sf}-1$} & Replace 75-watt Incandescent Flood Lamps with 23-watt CFLs & 48 & 3,965 & 696 & 39,295 & 57.50 & 0.2 \\
\hline & $\begin{array}{l}\text { Replace Existing } 100 \% \text { Efficient Electric Hot Water Heater with } \\
320 \% \text { Efficient Residential Add-On Heat Pump Water Heater; } \\
\text { Install Low-Flow Showerheads to Reduce Water Flow from } \\
\text { 4.8 GPM to } 2.0 \text { GPM } \\
\end{array}$ & 296 & 8,468 & 22,608 & 50,224 & 2.40 & 2.7 \\
\hline & Subtotal & 344 & 12,433 & 23,304 & 89,519 & 3.45 & 1.9 \\
\hline
\end{tabular}




\begin{tabular}{|c|c|c|c|c|c|c|c|}
\hline FEDS Category & Technology Change & $\begin{array}{c}\text { Energy } \\
\text { Savings } \\
(\text { MMBtu/yr) }\end{array}$ & $\begin{array}{c}\text { Annual } \\
\text { Savings } \\
(\$ / y r)\end{array}$ & $\begin{array}{c}\text { Capital Cost } \\
(\$)\end{array}$ & $\begin{array}{l}\text { Net Present } \\
\text { Value } \\
(\$)\end{array}$ & SIR & $\begin{array}{c}\text { Simple } \\
\text { Payback (yr) }\end{array}$ \\
\hline \multirow[t]{4}{*}{$30 \mathrm{sf}-4$} & $\begin{array}{l}\text { Replace 3x40-watt Incandescent Lamps with 2x9-watt CFLs and } \\
\text { ballast unit }\end{array}$ & 543 & 18,816 & 52,989 & 136,094 & 3.60 & 2.8 \\
\hline & Replace 60-watt Incandescent Flood Lamps with 18-watt CFLs & 54 & 6,679 & 960 & 66,479 & 70.30 & 0.1 \\
\hline & $\begin{array}{l}\text { Wrap Electric Hot Water Tank with R-11 Fiberglass Batt Insulation; } \\
\text { Install Low-Flow Showerheads to Reduce Water Flow from } 4.8 \\
\text { GPM to } 2.0 \mathrm{GPM} \text {; Install Faucet Aerators }\end{array}$ & 136 & 4,105 & 2,916 & 38,257 & 14.10 & 0.7 \\
\hline & Subtotal & 733 & 29,600 & 56,865 & 240,830 & 5.28 & 1.9 \\
\hline \multirow[t]{3}{*}{$40 \mathrm{a} 2$} & $\begin{array}{l}\text { Replace 40-watt T-12 Lamps and Magnetic Ballasts with 32-watt } \\
\text { T-8 Lamps and Electronic Ballasts }\end{array}$ & 2 & 62 & 343 & 281 & 1.80 & 5.5 \\
\hline & $\begin{array}{l}\text { Replace Existing 100\% Efficient Electric Hot Water Heater with } \\
370 \% \text { Efficient Commercial Heat Pump Water Heater; Install Faucet } \\
\text { Aerators }\end{array}$ & 0 & 21 & 44 & 136 & 3.00 & 2.1 \\
\hline & Subtotal & 2 & 83 & 387 & 417 & 1.99 & 4.7 \\
\hline \multirow[t]{2}{*}{ 40b } & $\begin{array}{l}\text { Replace 40-watt T-12 Lamps and Magnetic Ballasts with 32-watt } \\
\text { T-8 Lamps and Electronic Ballasts }\end{array}$ & 47 & 2,400 & 16,859 & 7,281 & 1.40 & 7.0 \\
\hline & Subtotal & 47 & 2,400 & 16,859 & 7,281 & 1.40 & 7.0 \\
\hline \multirow[t]{2}{*}{ 40c1 } & $\begin{array}{l}\text { Replace 2-watt LED Exit Signs with 0.35-watt Electroluminescent } \\
\text { Exit Signs }\end{array}$ & 0 & 30 & 252 & 39 & 1.20 & 8.4 \\
\hline & Subtotal & 0 & 30 & 252 & 39 & 1.20 & 8.4 \\
\hline \multirow[t]{2}{*}{ 40c2 } & $\begin{array}{l}\text { Replace 2-watt LED Exit Signs with 0.35-watt Electroluminescent } \\
\text { Exit Signs }\end{array}$ & 0 & 32 & 252 & 67 & 1.30 & 7.9 \\
\hline & Subtotal & 0 & 32 & 252 & 67 & 1.30 & 7.9 \\
\hline \multirow[t]{2}{*}{$50-2$} & $\begin{array}{l}\text { Replace 40-watt T-12 Lamps and Magnetic Ballasts with 32-watt } \\
\text { T-8 Lamps and Electronic Ballasts } \\
\end{array}$ & 15 & 667 & 2,995 & 3,709 & 2.20 & 4.5 \\
\hline & Subtotal & 15 & 667 & 2,995 & 3,709 & 2.20 & 4.5 \\
\hline \multirow[t]{4}{*}{$60 \mathrm{a} 1$} & $\begin{array}{l}\text { Insulate Perimeter of Slab on Grade Foundation with R-12.4 } \\
\text { Insulation }\end{array}$ & 19 & 668 & 6,414 & 282 & 1.04 & 9.6 \\
\hline & $\begin{array}{l}\text { Replace 2-watt LED Exit Signs with 0.2-watt Electroluminescent } \\
\text { Exit Signs }\end{array}$ & 1 & 132 & 1,015 & 314 & 1.30 & 7.7 \\
\hline & $\begin{array}{l}\text { Replace Existing 100\% Efficient Electric Hot Water Heater with } \\
\text { 370\% Efficient Commercial Heat Pump Water Heater }\end{array}$ & 66 & 2,357 & 2,802 & 19,337 & 5.50 & 1.2 \\
\hline & Subtotal & 86 & 3,157 & 10,231 & 19,933 & 2.70 & 3.2 \\
\hline
\end{tabular}




\begin{tabular}{|c|c|c|c|c|c|c|c|}
\hline FEDS Category & Technology Change & $\begin{array}{c}\text { Energy } \\
\text { Savings } \\
(\text { MMBtu/yr) }\end{array}$ & $\begin{array}{l}\text { Annual } \\
\text { Savings } \\
(\$ / y r)\end{array}$ & $\begin{array}{c}\text { Capital Cost } \\
(\$)\end{array}$ & $\begin{array}{l}\text { Net Present } \\
\text { Value } \\
\text { (\$) }\end{array}$ & SIR & $\begin{array}{c}\text { Simple } \\
\text { Payback (yr) }\end{array}$ \\
\hline \multirow[t]{6}{*}{$60 \mathrm{a} 2$} & Increase Insulation in Suspended Ceiling by R-11 from R-7 to R-18 & 307 & 11,356 & 93,677 & 20,230 & 1.20 & \begin{tabular}{|l|}
8.2 \\
\end{tabular} \\
\hline & $\begin{array}{l}\text { Insulate Perimeter of Slab on Grade Foundation with R-12.4 } \\
\text { Insulation }\end{array}$ & 22 & 769 & 7,071 & 640 & 1.10 & 9.2 \\
\hline & $\begin{array}{l}\text { Replace 2-watt LED Exit Signs with 0.35-watt Electroluminescent } \\
\text { Exit Signs }\end{array}$ & 1 & 95 & 754 & 222 & 1.30 & 7.9 \\
\hline & $\begin{array}{l}\text { Replace Existing 100\% Efficient Electric Hot Water Heater with } \\
\text { 370\% Efficient Commercial Heat Pump Water Heater }\end{array}$ & 26 & 883 & 1,593 & 6,409 & 3.60 & 1.8 \\
\hline & $\begin{array}{l}\text { Replace Existing 76\% Efficient Propane-Fired Hot Water Heater } \\
\text { with 370\% Efficient Commercial Heat Pump Water Heater }\end{array}$ & 36 & 583 & 1,593 & 4,146 & 2.70 & 2.7 \\
\hline & Subtotal & 392 & 13,686 & 104,688 & 31,647 & 1.28 & 7.6 \\
\hline \multirow[t]{4}{*}{$60 \mathrm{~b}$} & $\begin{array}{l}\text { Replace 96-watt T12 Fluorescent Lamps and Magnetic Ballasts with } \\
\text { Energy-Saving 96-watt T12 Lamps and Electronic Ballasts with } \\
\text { Reflectors }\end{array}$ & 333 & 13,173 & 56,254 & 76,080 & 2.40 & 4.3 \\
\hline & $\begin{array}{l}\text { Replace Existing Air-Cooled Electric Chiller }(\mathrm{COP}=2.53) \text { with Very } \\
\text { High Efficiency Water-Cooled Reciprocating Electric Chiller } \\
(\mathrm{COP}=4.2) \text { and Cooling Tower }\end{array}$ & 642 & 21,366 & 145,752 & 68,482 & 1.50 & 6.8 \\
\hline & $\begin{array}{l}\text { Wrap Electric Hot Water Tank with R-11 Fiberglass Batt Insulation; } \\
\text { Insulate Pipes Near Tank; Install Low-Flow Showerheads to Reduce } \\
\text { Water Flow from 4.8 GPM to } 2.0 \mathrm{GPM} \text {; Install Faucet Aerators; } \\
\text { Lower Tank Temperature from 140F to } 120 \mathrm{~F}\end{array}$ & 2 & 56 & 96 & 469 & 5.90 & 1.7 \\
\hline & Subtotal & 977 & 34,595 & 202,102 & 145,031 & 1.76 & 5.8 \\
\hline \multirow[t]{6}{*}{$60 c$} & $\begin{array}{l}\text { Replace 25-watt Incandescent Lamps with 5-watt CFLs and ballast } \\
\text { unit }\end{array}$ & 756 & 18,455 & 158,158 & 27,017 & 1.20 & 8.6 \\
\hline & $\begin{array}{l}\text { Replace 2-watt LED Exit Signs with 0.2-watt Electroluminescent } \\
\text { Exit Signs }\end{array}$ & 6 & 444 & 3,369 & 1,116 & 1.30 & 7.6 \\
\hline & $\begin{array}{l}\text { Replace 40-watt T-12 Lamps and Magnetic Ballasts with 32-watt } \\
\text { T-8 Lamps and Electronic Ballasts }\end{array}$ & 268 & 8,045 & 26,070 & 54,751 & 3.10 & 3.2 \\
\hline & $\begin{array}{l}\text { Replace Existing Air-Cooled Electric Chiller }(\mathrm{COP}=2.53) \text { with Very } \\
\text { High Efficiency Water-Cooled Reciprocating Electric Chiller } \\
(\mathrm{COP}=4.2) \text { and Cooling Tower }\end{array}$ & 968 & 31,637 & 191,088 & 125,887 & 1.70 & 6.0 \\
\hline & $\begin{array}{l}\text { Wrap Propane-Fired Hot Water Tank with R-11 Fiberglass Batt } \\
\text { Insulation }\end{array}$ & 462 & 8,377 & 338 & 92,253 & 274.00 & 0.0 \\
\hline & Subtotal & 2,460 & 66,958 & 379,023 & 301,024 & 1.87 & 5.7 \\
\hline
\end{tabular}




\begin{tabular}{|c|c|c|c|c|c|c|c|}
\hline FEDS Category & Technology Change & $\begin{array}{c}\text { Energy } \\
\text { Savings } \\
\text { (MMBtu/yr) }\end{array}$ & $\begin{array}{c}\text { Annual } \\
\text { Savings } \\
(\$ / y r)\end{array}$ & $\begin{array}{c}\text { Capital Cost } \\
(\$)\end{array}$ & $\begin{array}{l}\text { Net Present } \\
\text { Value } \\
\text { (\$) }\end{array}$ & SIR & $\begin{array}{c}\text { Simple } \\
\text { Payback (yr) }\end{array}$ \\
\hline \multirow[t]{5}{*}{80} & $\begin{array}{l}\text { Replace 2-watt LED Exit Signs with 0.2-watt Electroluminescent } \\
\text { Exit Signs }\end{array}$ & 13 & 1,302 & 9,491 & 3,663 & 1.40 & 7.3 \\
\hline & $\begin{array}{l}\text { Replace 40-watt T-12 Lamps and Magnetic Ballasts with 32-watt } \\
\text { T-8 Lamps and Electronic Ballasts with Reflectors }\end{array}$ & 78 & 2,923 & 11,167 & 18,198 & 2.60 & 3.8 \\
\hline & $\begin{array}{l}\text { Wrap Electric Hot Water Tank with R-11 Fiberglass Batt Insulation; } \\
\text { Insulate Pipes Near Tank; Install Low-Flow Showerheads to Reduce } \\
\text { Water Flow from } 4.8 \text { GPM to } 2.0 \text { GPM; Lower Tank Temperature } \\
\text { from 125F to } 120 \mathrm{~F}\end{array}$ & 1 & 42 & 330 & 95 & 1.30 & 7.9 \\
\hline & $\begin{array}{l}\text { Wrap Propane-Fired Hot Water Tank with R-11 Fiberglass Batt } \\
\text { Insulation }\end{array}$ & 194 & 3,511 & 200 & 38,612 & 193.90 & 0.1 \\
\hline & Subtotal & 286 & 7,778 & 21,188 & 60,568 & 3.88 & 2.7 \\
\hline \multicolumn{2}{|l|}{ Grand Total } & 20,179 & 663,317 & $2,812,712$ & $3,956,503$ & 2.45 & 4.2 \\
\hline
\end{tabular}

